\title{
Radiolarians in the Sea of Okhotsk and their ecological implication for paleoenvironmental reconstructions
}

\author{
A. Abelmann*, A. Nimmergut \\ Alfred Wegener Institute for Polar and Marine Research, Postfach 120161, 27515 Bremerhaven, Germany
}

Received 17 December 2003; accepted 27 July 2005

Available online 11 October 2005

\begin{abstract}
To assess the relationship of radiolarian production, species distribution in water and surface sediment to water-mass characteristics, biological productivity and export regimes in the Sea of Okhotsk (SOk) we accomplished a quantitative analysis of radiolarian assemblages obtained from 35 surface-sediment samples and 115 plankton samples recording the radiolarian depth distribution in the upper $1000 \mathrm{~m}$ of the water column at 23 locations. This study augments the knowledge on the autecological demands of radiolarians dwelling in a specific hydrographic and biological environment, and extracts new information on the significance of radiolarians for the assessment of past oceanographic and climatic development in high latitudes.

Highest radiolarian accumulation rates and seasonal radiolarian standing stocks are encountered in the western part of the SOk close to Sakhalin, marking the environmental conditions in this area as most favorable for radiolarian production. Maximum standing stocks occur during summer, indicating that the radiolarian signal preserved in the sediment record is mainly produced during this season when the mesopelagic biomass is at highest activity.

We identified seven radiolarian species and groups related to specific water-mass characteristics, depth habitats, and productivity regimes. Of those, Dictyophimus hirundo and Cycladophora davisiana are most prominent in the Sea of Okhotsk Intermediate Water $(200-1000 \mathrm{~m})$, the latter representing an indicator of the occurrence of cold and well ventilated intermediate/deep water and enhanced export of organic matter from a highly productive ocean surface. While Antarctissa (?) sp. 1 is typically related to the cold-water Sea of Okhotsk Dicothermal Layer (SODL), ranging between 50 and $150 \mathrm{~m}$ water depth, the surface waters above the SODL affected by strong seasonal variability are inhabited predominantly by taxa belonging to the Spongodiscidae, having a broad environmental tolerance. Taxa only found in the sediment record show that the plankton study did not cover all assemblages occurring in the modern SOk. This accounts for an assemblage restricted to the western Kurile Basin and apparently related to environmental conditions influenced by North Pacific and Japan Sea waters. Other important taxa include species of the Plagoniidae group, representing the most prominent contributors to the SOk plankton and surface sediments. These radiolarians show a more opportunistic occurrence and are indicative of high nutrient supply in a hydrographic environment characterized by pronounced stratification enhancing heterotrophic activity and phytodetritus export.
\end{abstract}

(C) 2005 Elsevier Ltd. All rights reserved.

Keywords: Radiolaria; Plankton; Surface sediments; Intermediate water; Mesopelagic; Sea of Okhotsk

*Corresponding author. Fax: + 404714831149.

E-mail address: abelmann@awi-bremerhaven.de (A. Abelmann). 


\section{Introduction}

The Sea of Okhotsk (SOk) (Fig. 1) a marginal sea of the North Pacific is suggested to present a modern analog of the glacial high-latitude ocean. Its unique environmental and hydrographic situation leads to the development and sedimentation of "glacial-type" radiolarian assemblages in plankton and surface sediments, respectively (Morley and Hays, 1983; Nimmergut and Abelmann, 2002; Hays and Morley, 2003; Okazaki et al., 2003). The productivity regime in the SOk is characterized by a pronounced yearly plankton succession that results in (1) high diatom production during spring that extends also into summer, and (2) high production of heterotrophic organisms during summer and early fall (Lapshina, 1996; Mordasova,
1997; Sorokin and Sorokin, 1999; Broerse et al., 2000). This leads to high biogenic opal accumulation, accounting for up to $40 \%$ and more of modern SOk sediments, composed of diatoms and radiolarians (Lisitzin, 1996; Biebow and Hütten, 1999).

Radiolarians are widely distributed in the world ocean and comprise surface and deep-living species that are adapted to specific water masses and watermass structures (Abelmann and Gowing, 1997; Kling and Boltovskoy, 1995; Nimmergut and Abelmann, 2002; Itaki, 2003; Itaki et al., 2003). Considering their habitats, radiolarians represent a promising tool to explore the mesopelagic environment in the geological past. Processes taking place in this environment play a significant role in the sequestration of organic carbon, and thus for global climate development. Such exploration requires

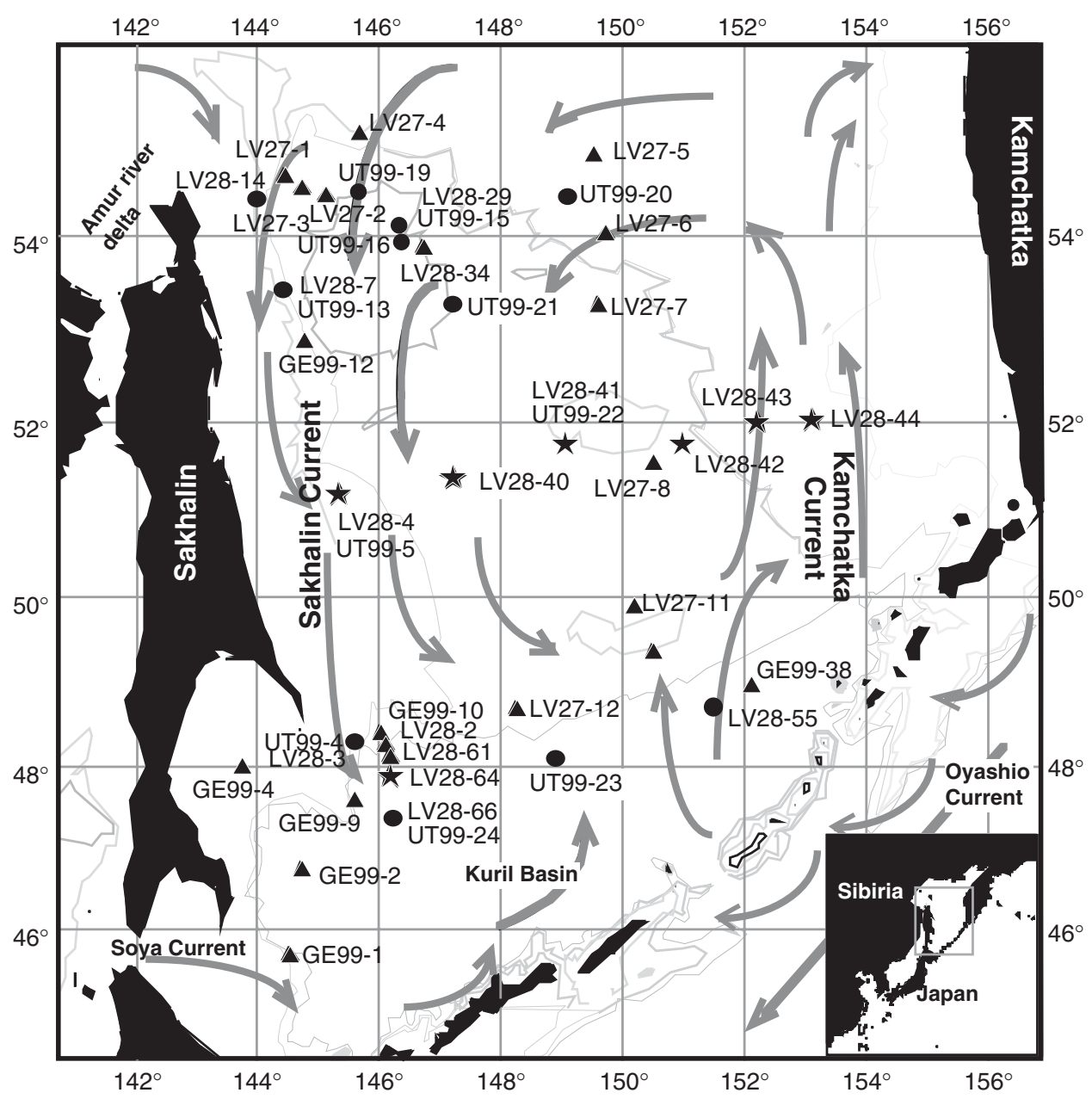

Fig. 1. Locations of surface-sediment and plankton samples presented in this study. Plankton stations are indicated by dots and surfacesediment samples by triangles. Stations where both plankton and surface sediments are taken are marked with an asterisk. Surface-water circulation in the Sea of Okhotsk (SOk) is marked by gray arrows. 
detailed ecological information about the relation of specific radiolarian key species to water-mass properties, feeding behavior, and rivalry strategies. The SOk, which is one of the most productive areas of the world ocean, is dominated by mesopelagic radiolarians (Nimmergut and Abelmann, 2002) and thus presents an ideal site to understand the ecological constraints that affect the distribution pattern of specific radiolarian species. We combined surface-sediment and plankton data gathered from the SOk in order to define radiolarian key species and their ecological requirements to reconstruct water-mass structures and productivity regimes in the geological past. In addition, we compare our results with recently accomplished seasonal flux studies of radiolarians from sediment traps located in the northeastern and western part of the SOk (Hays and Morley, 2003; Okazaki et al., 2003).

Previous studies of radiolarians in SOk surface sediments are based on the relative abundance pattern of one single radiolarian species (Cycladophora davisiana) or on a qualitative description of the radiolarian taxa (Ling, 1974; Kruglikova, 1975; Morley and Hays, 1983). The present study shows the first quantitative analysis of radiolarians in SOk surface sediments and comprises the estimation of radiolarian accumulation rates (RARs) that will be compared to the latitudinal pattern of the spring and summer radiolarian standing stocks extracted from recently accomplished plankton data (Nimmergut and Abelmann, 2002).

\section{Hydrographic setting}

The specific hydrographic conditions in the SOk are strongly related to the seasonal variation of the relatively stable atmospheric pressure cells and the polar jet stream (Fig. 2). During winter, the movement of polar air masses over the SOk causes extensive formation of sea ice covering most of the SOk (Alfultis and Martin, 1987; Talley and Nagata, 1995). The only ice-free region (except during very strong winters) is the Kamchatka Current area in the eastern SOk, which is influenced by the inflow of "warmer" North Pacific water via the Oyashio Current. During summer, warm and moisture-laden southwesterly winds lead to sea-ice melt and to a strong warming in the uppermost layer of the SOk waters reaching more than $14^{\circ} \mathrm{C}$ (Fig. 2). The warm and thin surface layer (upper $50 \mathrm{~m}$ ) is underlain by a near-freezing temperature minimum (remnant of winter water), which leads to the development of the

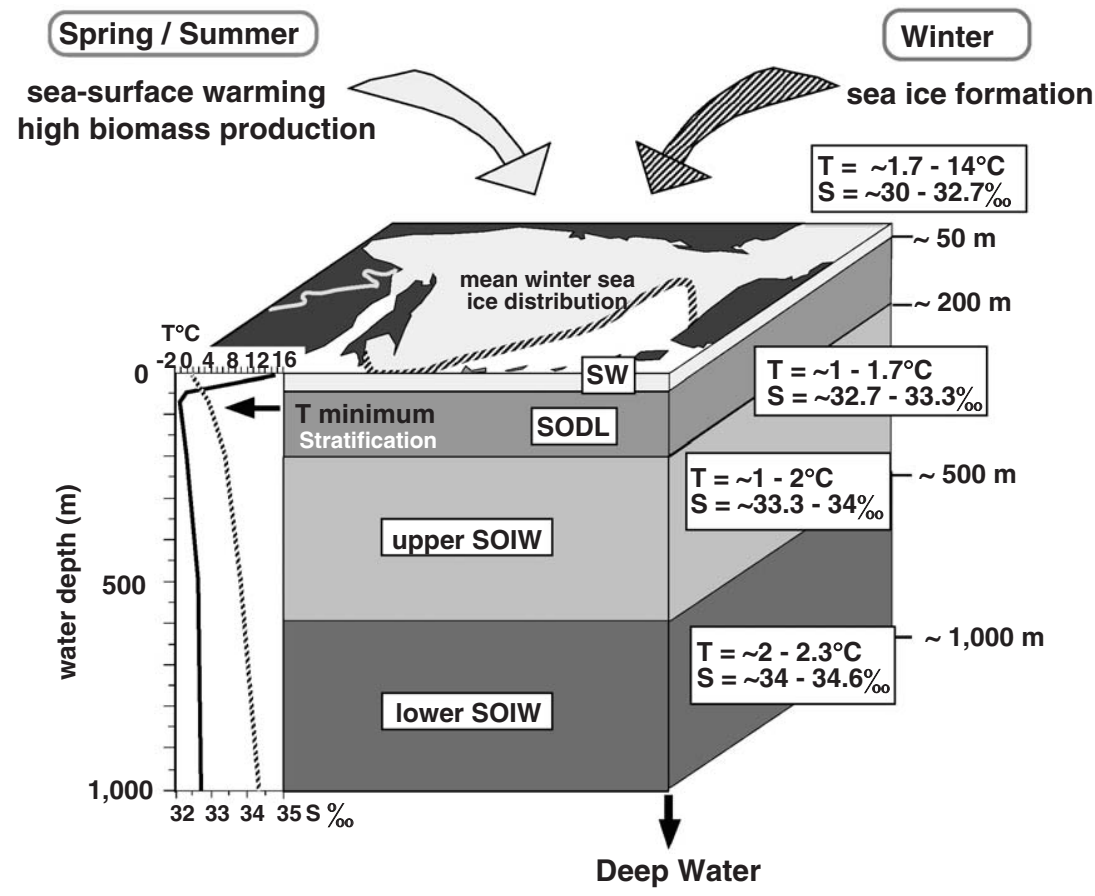

Fig. 2. Schematic presentation of the water-mass structure in the upper $1000 \mathrm{~m}$ and sea-ice distribution in the SOk. Indicated are temperature (black line) and salinity (gray line). SW, surface water; SODL, Sea of Okhotsk Dicothermal Layer; SOIW, Sea of Okhotsk Intermediate Water. 
Sea of Okhotsk Dicothermal Layer (SODL), resulting in a pronounced stratification of the upper $200 \mathrm{~m}$ during summer (Kitani, 1973; Yang and Honjo, 1996; Freeland et al., 1998). The relatively stable Sea of Okhotsk Intermediate Water (SOIW) occurs below the SODL (Fig. 2). The SOIW is suggested to be formed by isopycnal mixing of dense shelf-derived water with inflowing North Pacific water in the interior of the sea (Kitani, 1973; Freeland et al., 1998; Wong et al., 1998). The shelfderived water is formed during sea-ice formation by cooling and brine rejection (Kitani, 1973; Wong et al., 1998). The SOIW has colder temperature, lower salinity, and higher oxygen content compared with water of the same density in the North Pacific and is strongly related to sea-ice formation (Kitani, 1973; Wong et al., 1998). Wong et al. (1998) distinguished between an upper SOIW above a potential density of 27.0 (which is found approximately between 200 and $500 \mathrm{~m}$ depth) and a lower SOIW below (between 500 and $1000 \mathrm{~m}$ ) (Fig. 2). Recently, tritium and $\delta{ }^{18} \mathrm{O}$ data verify this subdivision due to the existence of a ventilated SOIW above $500 \mathrm{~m}$ depth in the northwestern part of the SOk (Winkler, 2000). In the following, we refer to the subdivision of Wong et al. (1998).

The SOk is affected by significant freshwater input through the Amur River, which accounts for about $37 \%$ of the freshwater supply into the SOk (Talley and Nagata, 1995). The Amur discharge, which follows the cyclonic gyre, flowing southward via the Sakhalin Current (Sapozhnikov et al., 1999), leads to a freshening of the upper sea surface especially in the northern and western part of the SOk during summer (Rogachev, 2000). Saline and relatively warm surface waters from the Japan Sea enter the SOk via the Soya Current over the shallow sill between Sakhalin and Hokkaido, and increase the salinity in surface waters of the southwestern SOk by mixing with the cold and low-salinity East Sakhalin Current (Yasuoka, 1967; Takizawa, 1982).

\section{Material and methods}

Surface-sediment and plankton samples from the SOk are collected during five cruises with different Russian research vessels (Nürnberg et al., 1997; Biebow and Hütten, 1999; Biebow et al., 2000, 2003) (Fig. 1, Table 1, Nimmergut and Abelmann, 2002). A total of 28 surface-sediment samples were taken with multiple corer (MUC) (Barnett et al., 1984) or mini-corer (MIC) (Kuhn and Dunker, 1994) devices
(Fig. 1). The studied surface-sediment samples generally comprise the topmost $0.5 \mathrm{~cm}$ of the sediment, carefully removed from one or two MUC or MIC tubes (diameter: $6 \mathrm{~cm}$ ). Altogether 115 plankton samples were collected at 23 locations with a multiple opening/closing sampling net device from five depth intervals over the upper $1000 \mathrm{~m}$ of the water column during spring (May 22-June 11, 1999) and summer (August 8-September 12, 1998) in combination with a CTD survey (Nimmergut and Abelmann, 2002).

For light microscopic investigations a quantitative sample preparation was made following AWI standard procedures (Abelmann, 1988; Abelmann et al., 1999). The plankton samples were oxidized with a saturated solution of potassium permanganate and afterward processed with $\mathrm{HCl}$ and $\mathrm{H}_{2} \mathrm{O}_{2}$; the surface sediments were processed with $\mathrm{H}_{2} \mathrm{O}_{2}$ and $\mathrm{HCl}$. All samples were rinsed over $41 \mu \mathrm{m}$. The microscopic slides with randomly distributed radiolarian skeletons (Abelmann et al., 1999) were mounted in Canada balsam. Light microscopic investigation was accomplished with a Leitz Orthoplan microscope with apochromatic objectives at a magnification of $160 \times, 250 \times$, and $400 \times$. Generally, more than 400 specimens were counted per sample except for the uppermost surface-water samples, where the radiolarian numbers are scarce.

A Q-mode factor analysis was performed on the surface and plankton data sets, respectively, by using a software package from Sieger et al. (1999). We used the complete data sets (radiolarian percentages) of both plankton and surface sediments, which comprises 50 polycystine radiolarian species in the plankton and 54 species in the surfacesediment data (Tables 2 and 3). The Q-mode factor analysis provides an objective quantitative means to simplify the complex radiolarian data set into a specific number of varimax factors and to select the most dominant species.

RARs are estimated according to

$\mathrm{RAR}\left(\right.$ Ind. $\left.\mathrm{m}^{-1} \mathrm{yr}^{-1}\right)=\mathrm{RC} \times \mathrm{DBD} \times \mathrm{LSR} \times 10$,

where $\mathrm{RC}$ is the radiolarian concentration (skeletons $\mathrm{g}^{-1}$ ), DBD is dry bulk density $\left(\mathrm{g} \mathrm{cm}^{-3}\right.$ ), and LSR is the linear sedimentation rate $\left(\mathrm{cm} 1000 \mathrm{yr}^{-1}\right)$. Linear sedimentation rates are based on age models assuming a constant sedimentation rate over the last $6 \mathrm{kyr}^{-1}$. The age assignment is based on a combination of oxygen isotopic, tephroand biostratigraphic records (Kaiser, 2001). 
Table 1

Geographic location (latitude, longitude, water depth) of the investigated surface sediment samples, sampling device (MUC, multi-corer; MIC, mini-corer), and linear sedimentation rates (LSR)

\begin{tabular}{|c|c|c|c|c|c|}
\hline Stations & Latitude $\left({ }^{\circ} \mathrm{N}\right)$ & Longitude $\left({ }^{\circ} \mathrm{E}\right)$ & Water depth (m) & Gear & $\operatorname{LSR}\left(\mathrm{cm} \mathrm{ka}^{-1}\right)$ \\
\hline \multicolumn{6}{|c|}{ Akademik Lavrentiev (1996) LV27 } \\
\hline LV27-1 & $54^{\circ} 34.56^{\prime}$ & $144^{\circ} 28.36^{\prime}$ & 1148 & MUC & 51 \\
\hline LV27-2 & $54^{\circ} 30.11^{\prime}$ & $144^{\circ} 45.33^{\prime}$ & 1273 & MUC & 53 \\
\hline LV27-3 & $54^{\circ} 24.83^{\prime}$ & $145^{\circ} 08.41^{\prime}$ & 1476 & MUC & 22 \\
\hline LV27-4 & $55^{\circ} 03.43^{\prime}$ & $145^{\circ} 44.08^{\prime}$ & 860 & MUC & 9 \\
\hline LV27-5 & $54^{\circ} 49.56^{\prime}$ & $149^{\circ} 32.22^{\prime}$ & 462 & MUC & 10 \\
\hline LV27-6 & $54^{\circ} 09.81^{\prime}$ & $149^{\circ} 30.09^{\prime}$ & 878 & MUC & 3 \\
\hline LV27-7 & $53^{\circ} 14.28^{\prime}$ & $149^{\circ} 34.37^{\prime}$ & 1150 & MUC & 4 \\
\hline LV27-8 & $51^{\circ} 29.82^{\prime}$ & $150^{\circ} 30.73^{\prime}$ & 1147 & MUC & 20 \\
\hline LV27-11 & $49^{\circ} 51.06^{\prime}$ & $150^{\circ} 19.07^{\prime}$ & 1151 & MUC & 16 \\
\hline LV27-12 & $48^{\circ} 42.50^{\prime}$ & $148^{\circ} 14.38^{\prime}$ & 1296 & MUC & 9 \\
\hline \multicolumn{6}{|c|}{ Akademik Lavrentiev (1998) LV28 } \\
\hline LV28-2 & $48^{\circ} 21.737^{\prime}$ & $146^{\circ} 02.071^{\prime}$ & 1286 & MUC & 26 \\
\hline LV28-4 & $51^{\circ} 08.897^{\prime}$ & $145^{\circ} 18.91^{\prime}$ & 675 & MUC & 140 \\
\hline LV28-34 & $53^{\circ} 51.914^{\prime}$ & $146^{\circ} 44.961^{\prime}$ & 1405 & MUC & 7 \\
\hline LV28-40 & $51^{\circ} 20.087^{\prime}$ & $147^{\circ} 13.090^{\prime}$ & 1313 & MUC & 21 \\
\hline LV28-41 & $51^{\circ} 41.478^{\prime}$ & $149^{\circ} 04.427^{\prime}$ & 1068 & MUC & 12 \\
\hline LV28-42 & $51^{\circ} 43.089^{\prime}$ & $150^{\circ} 59.716^{\prime}$ & 1036 & MUC & 12 \\
\hline LV28-43 & $51^{\circ} 54.461^{\prime}$ & $152^{\circ} 16.600^{\prime}$ & 842 & MUC & 37 \\
\hline LV28-44 & $52^{\circ} 01.152^{\prime}$ & $153^{\circ} 05.872^{\prime}$ & 694 & MUC & 25 \\
\hline LV28-61 & $48^{\circ} 10.318^{\prime}$ & $146^{\circ} 11.280^{\prime}$ & 1714 & MUC & - \\
\hline LV28-64 & $47^{\circ} 54.203^{\prime}$ & $146^{\circ} 07.110^{\prime}$ & 2480 & MUC & 50 \\
\hline \multicolumn{6}{|c|}{ Marshal Gelovany (1999) GE99 } \\
\hline Ge99-1 & $45^{\circ} 34.893^{\prime}$ & $144^{\circ} 20.395^{\prime}$ & 790 & MIC & - \\
\hline Ge99-2 & $46^{\circ} 41.692^{\prime}$ & $144^{\circ} 47.519^{\prime}$ & 3050 & $\mathrm{MIC}$ & - \\
\hline Ge99-4 & $48^{\circ} 01.499^{\prime}$ & $143^{\circ} 35.170^{\prime}$ & 75 & MIC & - \\
\hline Ge99-5 & $47^{\circ} 24.747^{\prime}$ & $145^{\circ} 23.048^{\prime}$ & 515 & MIC & - \\
\hline Ge99-6 & $47^{\circ} 21.188^{\prime}$ & $148^{\circ} 22.627^{\prime}$ & 3350 & MIC & - \\
\hline Ge99-10 & $48^{\circ} 18.309^{\prime}$ & $146^{\circ} 08.148^{\prime}$ & 1390 & MUC & 11 \\
\hline Ge99-12 & $52^{\circ} 50.787^{\prime}$ & $144^{\circ} 47.626^{\prime}$ & 930 & MUC & 122 \\
\hline Ge99-38 & $49^{\circ} 20.491^{\prime}$ & $150^{\circ} 29.809^{\prime}$ & 1100 & MIC & 2 \\
\hline
\end{tabular}

The geographic locations of the plankton samples are given in Nimmergut and Abelmann (2002).

\section{Results and discussion}

\subsection{Radiolarian accumulation in surface sediments}

The quantitative analyses of the surface-sediment record indicate that maximum radiolarian accumulation (of up to $1.9 \times 10^{6}$ skeletons $\mathrm{m}^{-2} \mathrm{yr}^{-1}$ ) occurs in the western part of the SOk close to the Sakhalin shelf, which implicates that the input of nutrients via the Amur River is a prominent factor controlling the productivity in SOk (Fig. 3). This finding is supported by the pattern of biogenic opal accumulation rates in the SOk surface sediments (Nürnberg et al., 2001) and by biological studies, which report highest productivity close to the shelf slopes off Sakhalin and Kamchatka (Arzhanova and Naletova, 1999; Sorokin and Sorokin, 1999). Radiolarians in the SOk mainly occur in deeper water layers, and highest standing stocks of radiolarians are found in mesopelagic depths during summer, a time with strongest sea-surface stratification (Nimmergut and Abelmann, 2002). Despite the pronounced seasurface stratification that generally results in nutrient exhaustions, the productivity on the shelves and at the shelf slopes off Sakhalin and Kamchatka remains enhanced also during summer, pointing to relatively high nutrient supply to the sea surface (Arzhanova and Naletova, 1999; Sorokin and Sorokin, 1999). Nutrients are advected by local upwelling along the shelf slopes of Kamchatka and Sakhalin caused by internal mixing of mesoscale rings and by the interaction of currents with the complex topography of the shelf slopes (Bulatov et al., 1999; Sorokin and Sorokin, 1999). Another 
Table 2

Varimax factor score matrix (species vs. factor scores) of the plankton data set

\begin{tabular}{|c|c|c|c|c|c|c|}
\hline Species & Factor 1 & Factor 2 & Factor 3 & Factor 4 & Factor 5 & Factor 6 \\
\hline Actinomma spp. & -0.004 & 0.001 & -0.019 & 0.002 & 0.114 & 0.002 \\
\hline Antarctissa (?) sp. 1 & -0.193 & -0.323 & 0.168 & 0.361 & 0.025 & \\
\hline Antarctissa (?) sp. 2 & 0.009 & 0.005 & 0.037 & 0.036 & -0.011 & -0.024 \\
\hline Artobotrys borealis & 0.004 & 0.001 & 0.002 & 0.001 & 0.002 & 0.000 \\
\hline Artostrobus jörgensenii & -0.001 & 0.000 & 0.000 & 0.000 & 0.007 & 0.006 \\
\hline Botryocampe inflata & 0.063 & -0.005 & 0.062 & -0.005 & 0.001 & 0.017 \\
\hline Botryocampe robusta & 0.016 & 0.001 & -0.007 & 0.007 & 0.006 & 0.002 \\
\hline Botryocyrtis scutum & 0.012 & -0.003 & 0.038 & -0.013 & -0.019 & -0.013 \\
\hline Centrocubus cladostylus & 0.000 & 0.002 & -0.005 & 0.000 & 0.027 & 0.000 \\
\hline Centrocubus cladostylus (?) (juvenile) & -0.005 & 0.001 & -0.005 & 0.000 & 0.039 & -0.001 \\
\hline Ceratocyrtis galea & 0.021 & -0.010 & 0.006 & 0.035 & 0.013 & 0.009 \\
\hline Ceratospyris borealis & 0.235 & -0.908 & 0.030 & -0.021 & 0.017 & 0.084 \\
\hline Cladococcus viminalis & 0.006 & 0.012 & -0.007 & 0.004 & 0.043 & 0.009 \\
\hline Cycladophora davisiana & 0.913 & 0.126 & 0.073 & -0.126 & 0.055 & -0.090 \\
\hline Dictyophimus hirundo & -0.070 & -0.004 & -0.167 & -0.003 & 0.892 & -0.027 \\
\hline Dictyophimus platycephalus & -0.001 & 0.000 & 0.001 & 0.000 & 0.003 & 0.002 \\
\hline Dictyophimus spp. (juvenile) & 0.015 & 0.002 & 0.008 & 0.027 & 0.004 & -0.010 \\
\hline Eucyrtidium acuminatum & 0.016 & 0.003 & -0.009 & -0.002 & 0.021 & -0.005 \\
\hline Litharachnium tenthorium & 0.019 & 0.001 & -0.007 & -0.001 & 0.017 & -0.001 \\
\hline Litheliidae (juvenile) & -0.008 & -0.001 & 0.010 & 0.023 & 0.008 & 0.018 \\
\hline Lithomelissa setosa & 0.007 & 0.001 & 0.008 & 0.002 & 0.006 & 0.007 \\
\hline Lithomelissa/ Trisulcus sp. 1 (juvenile) & -0.010 & -0.006 & 0.015 & 0.049 & 0.001 & -0.046 \\
\hline Lophophaena spp. & 0.004 & 0.000 & 0.002 & -0.003 & 0.015 & -0.004 \\
\hline Lophospyris sp. 1 & 0.020 & 0.027 & -0.041 & 0.016 & 0.197 & 0.013 \\
\hline Nassellaria sp. 1 (juvenile) & -0.003 & -0.001 & 0.016 & -0.003 & -0.003 & 0.009 \\
\hline Nassellaria spp. & 0.080 & 0.003 & -0.034 & 0.030 & 0.142 & 0.063 \\
\hline Peridium longispinum & -0.004 & 0.009 & 0.029 & 0.008 & 0.032 & 0.006 \\
\hline Peridium sp. 1 & 0.020 & 0.024 & -0.048 & 0.019 & 0.247 & -0.001 \\
\hline Phormacantha hystrix & -0.008 & -0.012 & 0.037 & 0.089 & -0.012 & -0.047 \\
\hline Phormostichoartus platycephala & 0.003 & -0.001 & -0.003 & 0.001 & 0.005 & 0.006 \\
\hline Plagoniidae & -0.017 & 0.087 & 0.939 & 0.051 & 0.182 & 0.054 \\
\hline Pseudodictyophimus gracilipes & 0.006 & 0.007 & -0.011 & 0.000 & 0.123 & 0.005 \\
\hline Pylosira sp. aff. Pylosira octopyle & 0.008 & 0.000 & -0.008 & 0.013 & 0.022 & -0.001 \\
\hline Rhizoplegma boreale & 0.208 & 0.128 & -0.111 & 0.913 & -0.026 & 0.163 \\
\hline Sethoconus tabulatus & 0.009 & 0.001 & 0.005 & -0.001 & 0.001 & 0.000 \\
\hline Siphocampe lineata & 0.009 & 0.005 & -0.005 & 0.003 & 0.024 & 0.003 \\
\hline Spongodiscidae & -0.102 & -0.048 & 0.143 & 0.018 & 0.004 & 0.680 \\
\hline Spongopyle osculosa & 0.010 & 0.003 & -0.012 & 0.004 & 0.029 & 0.015 \\
\hline Spongotrochus glacialis & -0.029 & -0.143 & -0.063 & 0.033 & 0.032 & 0.369 \\
\hline Spongotrochus spp. & -0.001 & -0.086 & -0.054 & 0.026 & 0.017 & 0.267 \\
\hline Spongurus pylomaticus & 0.011 & 0.004 & -0.014 & 0.001 & 0.046 & 0.001 \\
\hline Spumellaria spp. & 0.020 & -0.001 & -0.010 & 0.008 & 0.044 & 0.031 \\
\hline Stylatractus (?) pyriformis & 0.000 & 0.002 & -0.003 & 0.001 & 0.018 & 0.002 \\
\hline Stylochlamidium venustum & -0.001 & -0.006 & 0.016 & -0.003 & 0.010 & 0.013 \\
\hline Stylodictya aculeata & 0.003 & 0.001 & 0.000 & 0.000 & 0.001 & 0.001 \\
\hline Stylodictya validispina & -0.001 & 0.000 & 0.000 & 0.000 & 0.001 & 0.001 \\
\hline Tholospira spp. & -0.007 & -0.003 & 0.016 & 0.009 & 0.000 & -0.005 \\
\hline Tholospyris gephyristes & 0.006 & 0.006 & -0.010 & 0.002 & 0.049 & -0.001 \\
\hline Trisulcus borealis & 0.019 & 0.006 & 0.019 & 0.001 & -0.008 & 0.007 \\
\hline Trisulcus spp. & 0.001 & 0.011 & 0.024 & 0.004 & -0.003 & 0.022 \\
\hline
\end{tabular}

The most dominant species for each factor are highlighted in bold.

nutrient supply mechanism is the remineralization of organic matter related to the activity of the extremely abundant micro- and mesozooplankton
(Agatova et al., 1996). In contrast to the shallow and broad Kamchatka shelf, the Sakhalin shelf is relatively narrow and steep, allowing the 
Table 3

Varimax factor score matrix (species vs. factor scores) of the surface sediment data set

\begin{tabular}{|c|c|c|c|}
\hline Species & Factor A & Factor B & Factor C \\
\hline Actinomma spp. & -0.027 & 0.011 & 0.049 \\
\hline Antarctissa (?) sp. 1 & 0.048 & 0.107 & 0.021 \\
\hline Antarctissa (?) sp. 2 & 0.157 & -0.013 & -0.015 \\
\hline Artobotrys borealis & 0.032 & -0.002 & 0.007 \\
\hline Artostrobus jörgensenii & -0.005 & -0.009 & 0.047 \\
\hline Botryocampe inflata & 0.139 & 0.146 & -0.021 \\
\hline Botryocampe robusta & -0.009 & 0.013 & 0.013 \\
\hline Botryocyrtis scutum & 0.005 & -0.005 & 0.006 \\
\hline Centrocubus cladostylus & -0.001 & -0.004 & 0.021 \\
\hline Ceratocyrtis galea & 0.003 & 0.024 & -0.009 \\
\hline Ceratospyris borealis & -0.018 & 0.451 & -0.079 \\
\hline Cornutella bimarginata & -0.005 & -0.005 & 0.022 \\
\hline Cycladophora cornuta & -0.020 & 0.002 & 0.046 \\
\hline Cycladophora davisiana & 0.045 & 0.825 & 0.137 \\
\hline Cyrtopera laguncula & -0.007 & 0.002 & 0.021 \\
\hline Dictyophimus bicornis & 0.003 & 0.011 & -0.005 \\
\hline Dictyophimus gracilipes & -0.033 & 0.099 & 0.114 \\
\hline Dictyophimus hirundo & -0.015 & 0.060 & 0.066 \\
\hline Dictyophimus platycephalus & -0.010 & 0.000 & 0.046 \\
\hline Dictyophimus spp. (juvenile) & 0.018 & 0.012 & 0.020 \\
\hline Eucyrtidium acuminatum & -0.003 & 0.007 & 0.001 \\
\hline Litharachnium tenthorium & -0.006 & 0.009 & 0.002 \\
\hline Litheliidae & -0.027 & 0.047 & 0.095 \\
\hline Lithelius spiralis & -0.005 & 0.002 & 0.012 \\
\hline Lithomelissa setosa & -0.150 & -0.097 & 0.860 \\
\hline Lophophaena spp. & 0.002 & 0.010 & 0.004 \\
\hline Lophospyris sp. 1 & -0.005 & 0.051 & 0.070 \\
\hline Nassellaria spp. & 0.072 & 0.082 & 0.033 \\
\hline Peridium longispinum & 0.001 & -0.005 & 0.034 \\
\hline Peridium sp. 1 & -0.004 & 0.040 & 0.034 \\
\hline Phormacantha hystrix & -0.013 & 0.021 & 0.046 \\
\hline Phormostichoartus platycephala & 0.012 & 0.033 & 0.006 \\
\hline Plagoniidae & 0.933 & -0.084 & 0.203 \\
\hline Pseudocubus obeliscus & 0.007 & -0.004 & -0.002 \\
\hline Pylosira sp. aff. Pylosira octopyle & -0.016 & 0.071 & 0.025 \\
\hline Radiolaria spp. & 0.056 & 0.029 & -0.019 \\
\hline Rhizoplegma boreale & 0.097 & 0.085 & -0.049 \\
\hline Rhizoplegma boreale (juvenile) & 0.044 & 0.052 & -0.033 \\
\hline Sethoconus tabulatus sp. 2 & 0.002 & 0.001 & 0.020 \\
\hline Sethoconus tabulatus sp. 1 & 0.040 & 0.082 & 0.001 \\
\hline Sethophormis rotula & -0.005 & 0.009 & 0.000 \\
\hline Siphocampe arachnea & -0.034 & -0.050 & 0.250 \\
\hline Siphocampe lineata & 0.131 & -0.005 & -0.065 \\
\hline Spongotrochus glacialis & -0.004 & 0.045 & -0.019 \\
\hline Spongotrochus glacialis (juvenile) & 0.005 & 0.001 & 0.004 \\
\hline Spongotrochus spp. & 0.005 & 0.004 & -0.004 \\
\hline Stylatractus (?) pyriformis & -0.105 & 0.050 & 0.241 \\
\hline Stylochlamidium venustum & 0.040 & 0.046 & -0.043 \\
\hline Stylochlamidium venustum (juvenile) & -0.012 & 0.027 & 0.025 \\
\hline Spumellaria spp. & 0.015 & 0.059 & 0.009 \\
\hline Tholospria sp. & -0.006 & -0.009 & 0.032 \\
\hline Tholospyris gephyristes & -0.023 & 0.025 & 0.071 \\
\hline Trisulcus borealis & 0.010 & 0.025 & -0.015 \\
\hline Trisulcus spp. & -0.017 & 0.005 & 0.075 \\
\hline
\end{tabular}

The most dominant species for each factor are highlighted in bold. mesopelagic radiolarian community to benefit from the high primary productivity of this area. The correlation of the latitudinal distribution of RARs in surface sediments and radiolarian standing stock values averaged over the upper $1000 \mathrm{~m}$ shows a strong accordance between the summer radiolarian standing stock and the RAR in surface sediments and indicates that the signal preserved in the sediment record is produced during summer or fall (Fig. 3).

Our finding is supported by sediment trap studies, which show that the main radiolarian export in the SOk occurs during August and November (Hays and Morley, 2003; Okazaki et al., 2003) whereas the main diatom export occurs during spring (Broerse et al., 2000). As discussed in Nimmergut and Abelmann (2002), the anti-correlation between diatom and radiolarian export might be caused by the specific radiolarian assemblage in the SOk mainly composed of rather small deep-living nassellarians, which seems to have different food requirements than radiolarian assemblages in other ocean areas, as the Southern Ocean, the Nordic Seas, and the North Pacific where the export production of radiolarians and diatoms is more or less coupled (Abelmann and Gersonde, 1991; Samtleben et al., 1995; Takahashi, 1997; Tsoi et al., 1998). Small deep-living protozoans such as deep-living nassellarians in the SOk feed mainly on detritus or/and bacteria, transported with the sinking organic matter from the sea surface to deeper water (Anderson, 1983; Anderson et al., 1989). The interplay of high productivity during spring and summer and the specific hydrographic structure in the SOk favors the activity of microheterotrophs (e.g., bacteria and protozoa) that causes the high degradation of organic matter reported from subsurface to intermediate depths in the SOk (Sorokin, 1978; Azam et al., 1983; Sorokin and Sorokin, 1999).

\subsection{Definition of radiolarian key species}

We identified the most dominant polycystine radiolarian species in the plankton and in surface sediments by running a Q-mode factor analysis on both the plankton and the sediment data sets. Results of the factor analyses are presented in Tables 2 and 3 (varimax factor score matrix). The varimax factor matrix of the plankton and surface-sediment data sets are electronically available at: http://doi.pangaea.de/ 10.1594/PANGAEA.256487 and http://doi.pangaea. 

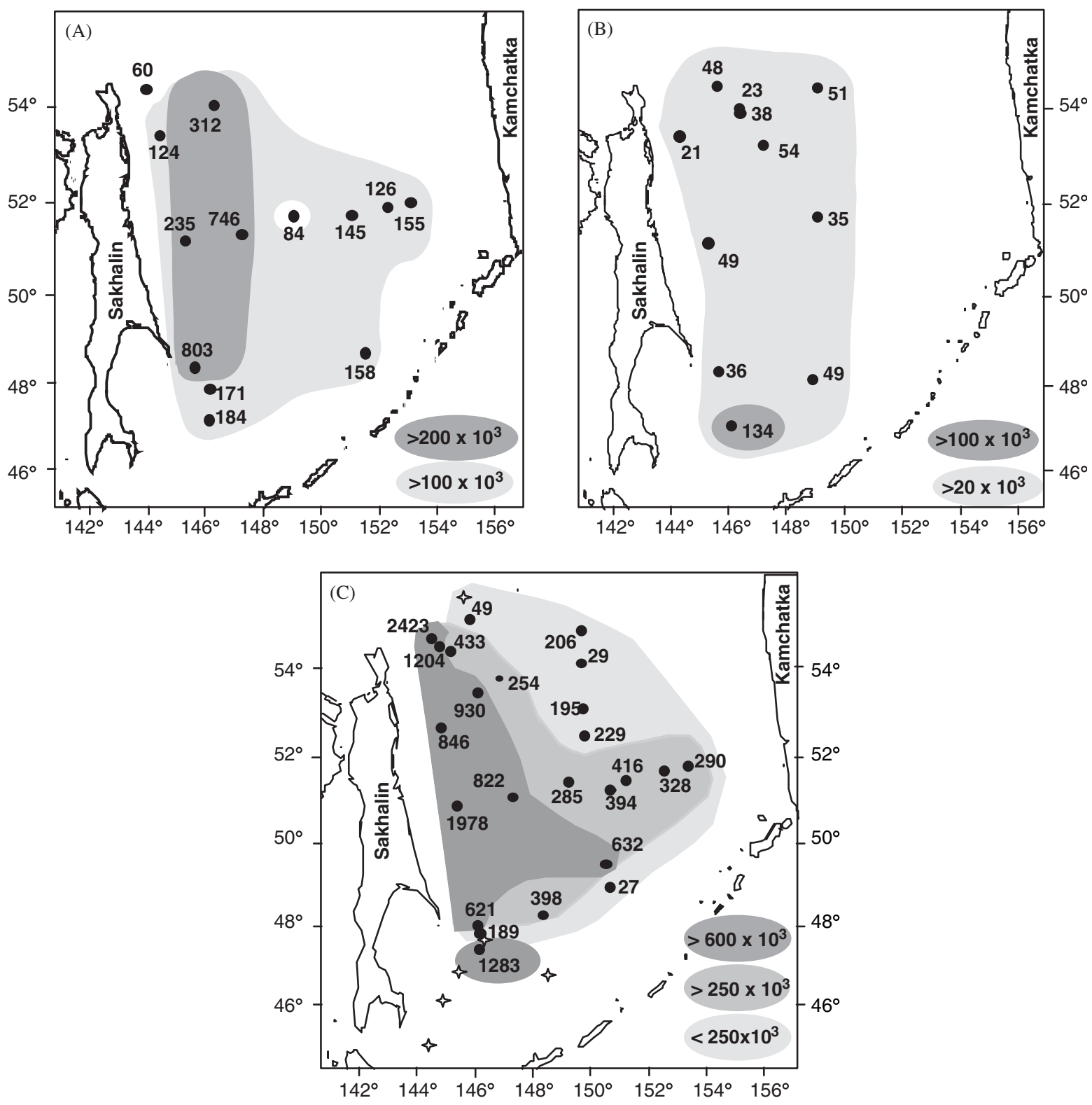

Fig. 3. Comparison of radiolarian standing stock data (Ind. $\mathrm{m}^{-3}$ ) in the SOk (A) during summer and (B) during spring, with (C) radiolarian accumulation rates (RAR, Ind. $\mathrm{m}^{-2} \mathrm{yr}^{-1}$ ) in surface sediments. Stations are marked with an asterisk where RAR could not be estimated due to lacking age assignment.

de/10.1594/PANGAEA.256489. The Q-mode factor analysis of the radiolarian plankton data set results in the definition of six varimax factors or assemblages, which explain $94 \%$ of the total information of the species included. Each factor is dominated by one or two species, which can be defined as the main players or key species and exhibits a specific depth range and seasonal related dominance. These are species grouped into the Plagoniidae and Spongo- discidae, and species such as $C$. davisiana, Ceratospyris borealis, Rhizoplegma borealis, Antarctissa (?) sp. 1 and Dictyophimus hirundo. The application of the factor analysis on the surface-sediment data set resulted in the definition of three factors, explaining $94 \%$ of the data. Two factors are governed by the Plagoniidae group (Factor A), and C. davisiana and C. borealis (Factor B). Factor B combines two species, which inhabit different depth intervals in 
the water column and are related to different ecological conditions. The third assemblage (Factor C) is dominated by Lithomelissa setosa, Siphocampe arachnea, and Stylatractus (?) pyriformis, taxa that are not recorded in the plankton data. This mismatch between plankton and sediment data might result from the sequence of time represented in the two data sets. The plankton data present a snap-shot-like signal and reflect the species or factor relation to specific physical and biological conditions at the time of sampling. The surfacesediment data represent an integrated signal, which includes seasonal and also inter-annual changes in the hydrographic and biological system, forced by short-scale climate variations. The ecological significance of the eight key species and assemblages and their relation to the SOk hydrography and productivity regime are presented and discussed in the following, based on their abundance distribution in the water column and surface sediments.

\subsection{Modern SOk productivity assemblage}

The most prominent taxon in the SOk plankton and surface sediments is the Plagoniidae group (Figs. 4, 5 and 6.3-6.4; Tables 2-5). The Plagoniidae are mainly composed of the taxon Plectacantha oikiskos Jørgensen. Because of the high morphological variability of this group and the lack of significant criteria for separating all specimens from the genera Plagiacantha, Phormacantha, Plectacantha, and Arachnocorys, we grouped them under the family name Plagoniidae. The high abundances of Plagoniidae, documented in this study, have not been reported from sediment trap investigations recently accomplished in the SOk (Hays and Morley, 2003; Okazaki et al., 2003). This discrepancy results from the use of different mesh sieve sizes utilized for the concentration of radiolarians for microscopic investigations. For the sediment trap investigations a mesh size of $6 \mu \mathrm{m}$ has been applied, whereas in this study sediment and plankton samples were sieved over $41 \mu \mathrm{m}$. The modern SOk radiolarian fauna mainly consists of small nassellarians including a high portion of juveniles (Nimmergut and Abelmann, 2002). For this reason, sole consideration of radiolarians obtained from the fraction $>63 \mu \mathrm{m}$ strongly biases total radiolarian numbers and the relative contribution of radiolarian species and species groups, especially in the SOk.
The highest relative abundances of the Plagoniidae group occur in the vicinity of the shelf areas off Kamchatka and Sakhalin, where the biological productivity is high, as indicated in the increased chlorophyll concentrations (Fig. 5). The Plagoniidae, accumulated in a band across the central part of the SOk, might be transported with the cyclonic circulation from the Sakhalin shelf into the central part of the basin. Maximum accumulation and relative numbers of this species group occur along Sakhalin in the upper $1000 \mathrm{~m}$, and might be strongly affected by a combination of several environmental factors: steep shelf, high nutrient supply via the Amur River, and mixing processes at the shelf slope (Bulatov et al., 1999; Sapozhnikov et al., 1999; Sorokin and Sorokin, 1999). This is in accordance with other studies, which described the Plagoniidae to be dominant in high-latitude neritic environments, such as the Antarctic shelf areas and the coastal waters off Norway and Vancouver, characterized by high biological productivity, and also by a specific morphology such as fjords and steep shelf slopes (Jørgensen, 1905; Wailes, 1937; Abelmann, 1992a, b; Nishimura et al., 1997). In the SOk plankton, Plagoniidae are most dominant during summer, ranging over a water depth of 0 and $1000 \mathrm{~m}$, while they exhibit only very low abundances during spring (Fig. 4, Nimmergut and Abelmann, 2002). This is in agreement with radiolarian flux data recorded from sediment traps of the SOk where species belonging to the Plagoniidae group such as Arachnocorys dubius and Phormacanta spp. show maximum fluxes between August and October (Hays and Morley, 2003; Okazaki et al., 2003). These data indicate that the Plagoniidae are not strongly related to specific water-mass properties and that food supply is the main factor controlling the distribution pattern of the species group in the SOk. We assume that they primarily feed on phytodetritus released from the highly productive surface of the shelf slopes or/and on bacteria attached to the organic matter, due to the enhanced heterotrophic activity during summer (Sorokin and Sorokin, 1999). For this reason, we conclude that the Plagoniidae are indicative for the modern high productivity system in the SOk, characterized mainly by the interaction of two factors: (1) high nutrient supply, which promotes phytoplankton production during summer and (2) a strongly stratified water column that favors high heterotrophic activity and enhances the phytodetritus export during this time interval. 
Spring

Depth Intervals

Spongodiscidae

C. borealis

Antarctissa sp. 1

R. boreale

C. davisiana

D. hirundo
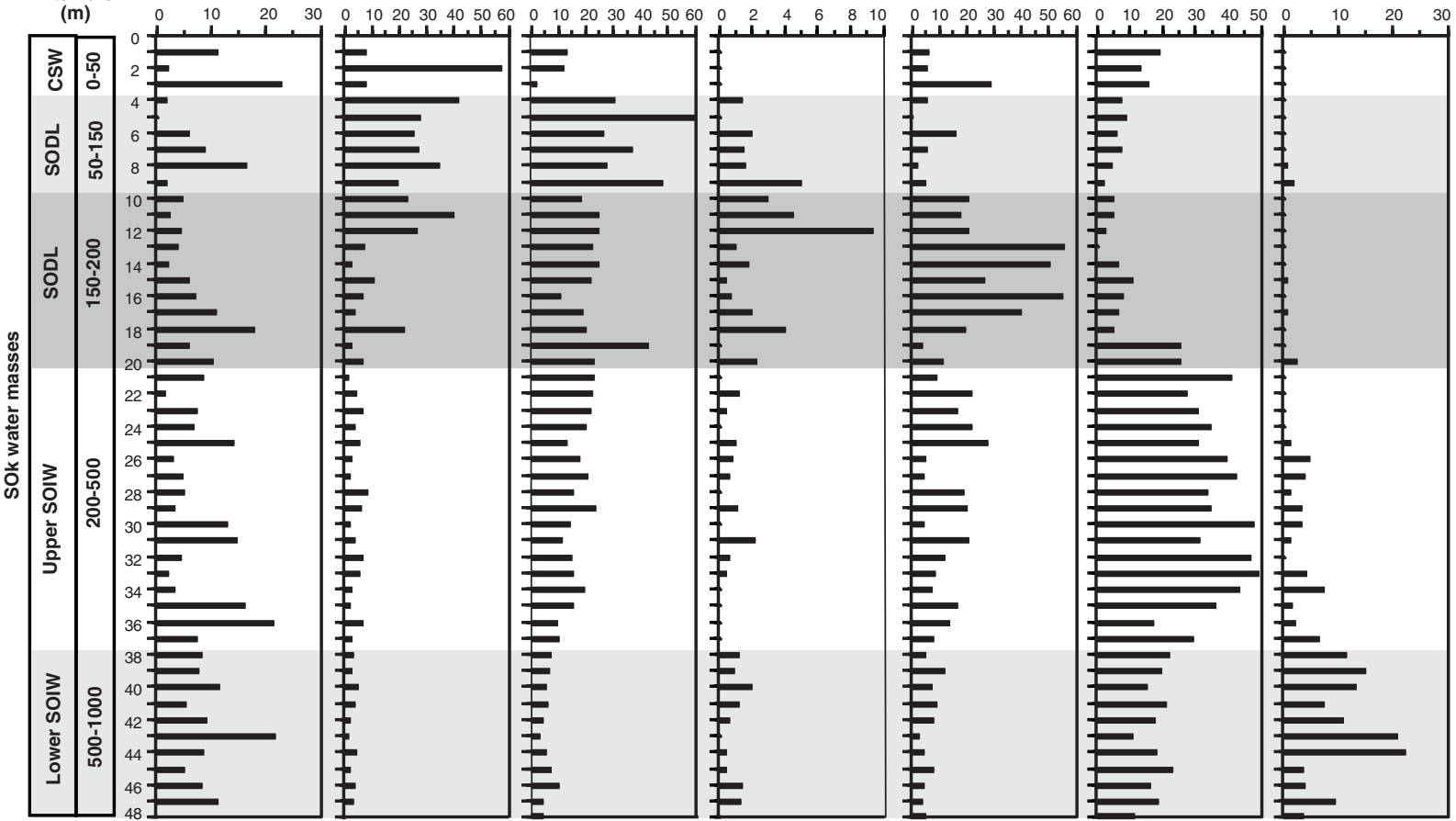

\section{Summer}

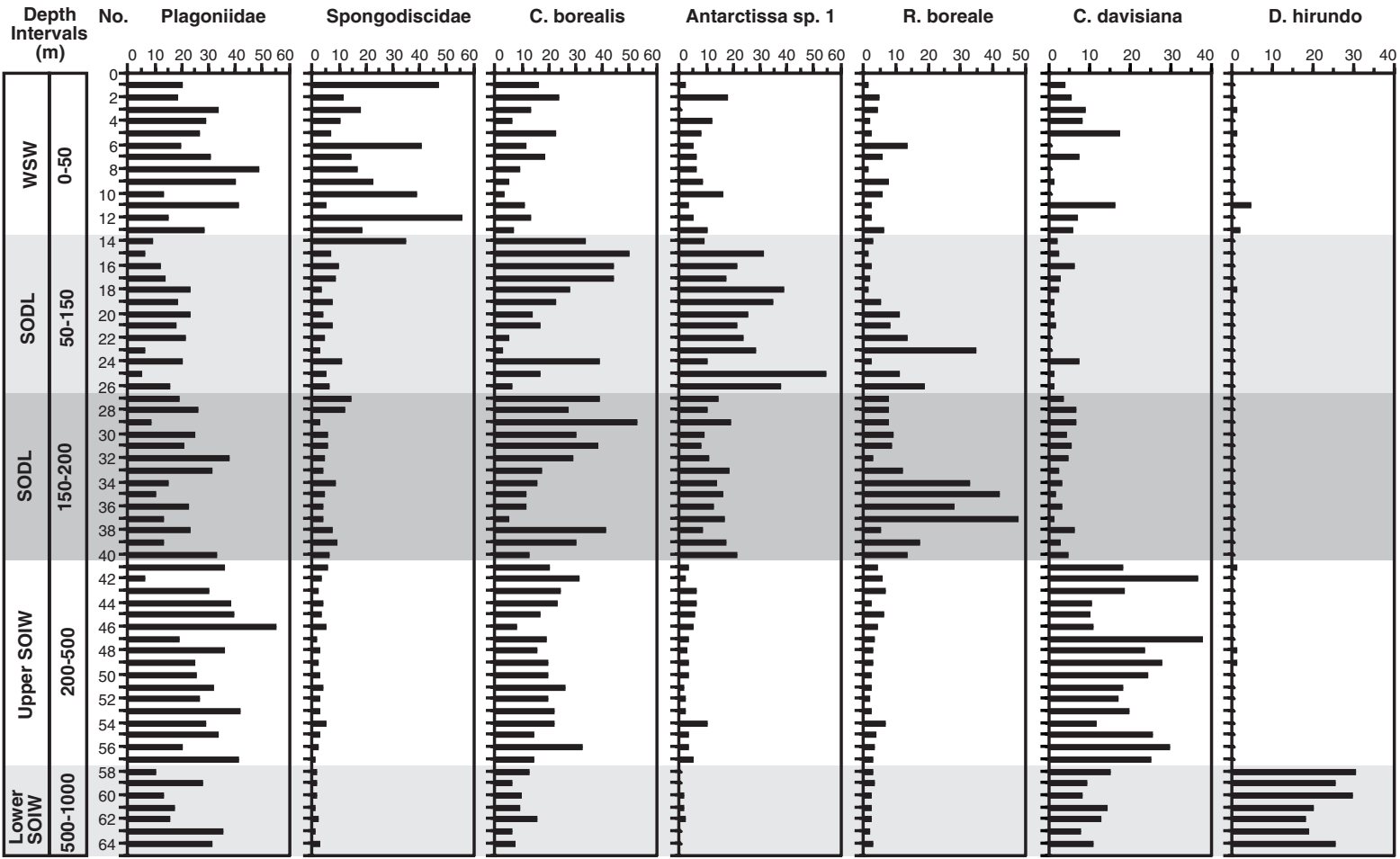

Fig. 4. Relative abundance patterns (\%) of the most dominant radiolarian taxa in the water column during spring and summer, in relation to water depth and SOk water masses. Indicated are sample numbers (No.). The depth interval of each sample in relation to sample number is given in Tables 4 and 5. CSW, cold surface water; WSC, warm surface water; SODL, Sea of Okhotsk Dicothermal Layer; SOIW, Sea of Okhotsk Intermediate Water. 

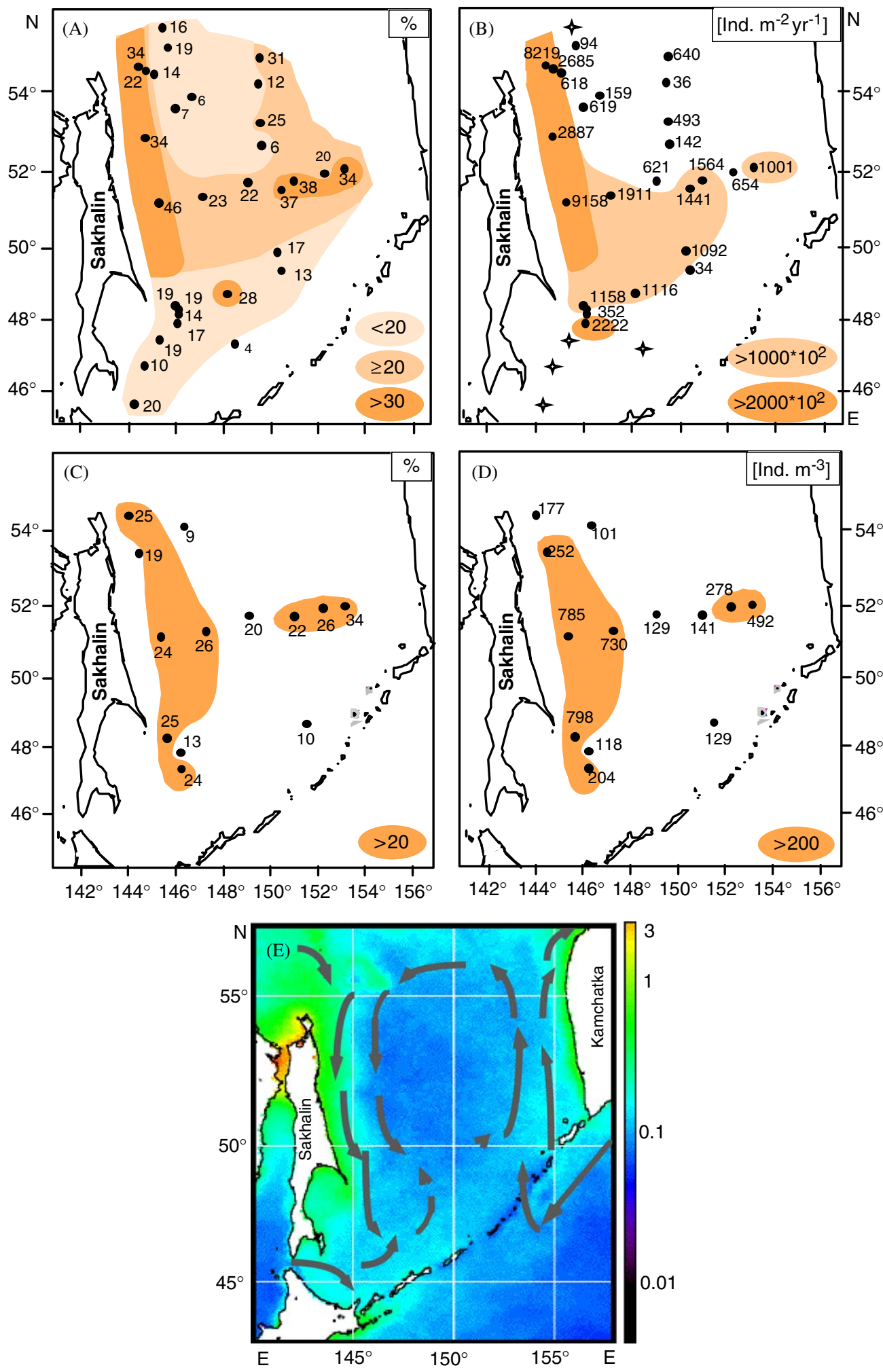

Fig. 5. Comparison of the distribution pattern of the Plagoniidae group in surface sediments and its latitudinal distribution averaged over the upper $1000 \mathrm{~m}$ of the water column with chlorophyll data. Indicated are (A) relative abundances and (B) accumulation rates in surface sediments, (C) relative abundances and (D) standing stocks during summer, (E) SOk chlorophyll composites (August 1997-November 2002) from SeaWiFS. 

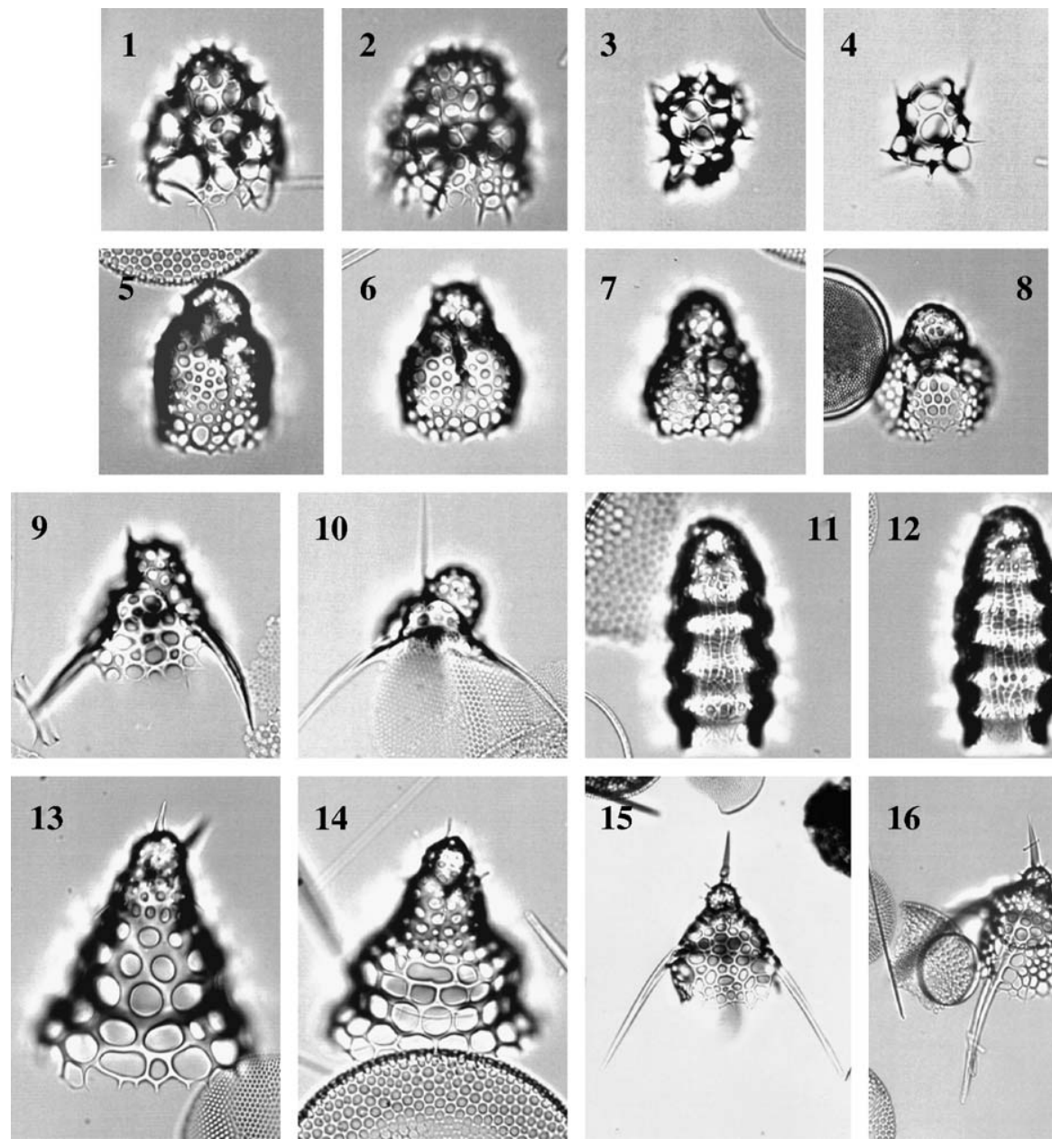
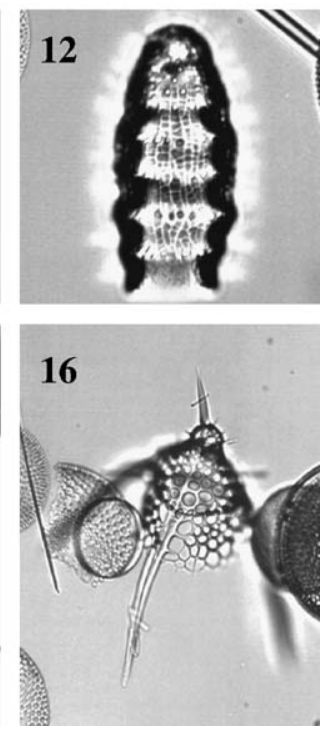

Fig. 6. Radiolarians from surface sediments of the Sea of Okhotsk. Scale bars are indicated on Plate II. Scale bar A is for photographs 1-14, 18, 20-22, and 25-26; scale bar B is for photographs 15-17, 19, and 24; and scale bar C is for photograph 23 and 6.1.-6.2. Antarctissa (?) sp. 1 (LV28-34-1), 6.3.-6.4. Plagoniidae group (LV28-34-1), 6.5.-6.8. Lithomelissa setosa (LV28-34-1), 6.9.-6.10. Pseudodictyophimus gracilipes (LV28-34-1), 6.11.-6.12. Siphocampe arachnea (LV28-2-2), 6.13. Cycladophora davisiana (LV28-2-2), 6.14. Cycladophora davisiana (LV28-2-2), 6.15.-6.16. Dictyophimus hirundo (LV28-2-2).

\subsection{Surface-water assemblage}

The SOk surface waters are affected by strong seasonal hydrographic variations ranging from seaice coverage in winter to warming of the sea surface to more than $14{ }^{\circ} \mathrm{C}$ during summer. Salinity values are rather low in the northwestern part due to the Amur discharge, and higher in the southeastern and southwestern areas due to the influence of the Kamchatka and Soya Currents, respectively. These strong seasonal and latitudinal changes result in low radiolarian abundances in the surface layer and affect the faunal composition (Nimmergut and Abelmann, 2002). The only radiolarians that dominate the surface waters belong to the Spongo- discidae group. This species group occurs in the upper $50 \mathrm{~m}$ during summer, whereas during spring, when the sea-surface stratification is not yet developed, it dwells at depth up to 150-200 m below surface (Fig. 4). The Spongodiscidae group mainly comprises juvenile and adult forms of Spongotrochus glacialis and Stylochlamydium venustum (Figs. 7.23-7.26). However, we assume that most of these juveniles belong to $S$. venustum, because mainly adults and also juvenile specimens of this species are recorded in surface sediments, whereas $S$. glacialis occurs in rare numbers. Both species are reported to live in surface-water environments with broad temperature and salinity ranges and to be prominent members of the radiolarian assemblages 
Table 4

Percentages of the dominant species in the spring plankton data set (UT stations)

\begin{tabular}{|c|c|c|c|c|c|c|c|c|}
\hline No. & Station, depth (m) & Plagoniidae & Spongodiscidae & C. borealis & Antarctissa sp. 1 & R. boreale & C. davisiana & D. hirundo \\
\hline 1 & UT99-21, 0-50 & 10.9 & 7.8 & 12.5 & 0 & 6.3 & 18.8 & 0 \\
\hline 2 & UT99-15, 0-50 & 1.9 & 57.4 & 11.1 & 0 & 5.6 & 13 & 0 \\
\hline 3 & UT99-5, 0-50 & 22.7 & 7.6 & 1.5 & 0 & 28.8 & 15.2 & 0 \\
\hline 4 & UT99-15, 50-150 & 1.7 & 41.7 & 29.8 & 1.3 & 5.6 & 7 & 0 \\
\hline 5 & UT99-20, 50-150 & 0 & 27.7 & 59.6 & 0 & 0 & 8.5 & 0 \\
\hline 6 & UT99-21, 50-150 & 5.7 & 25.6 & 25.9 & 1.9 & 16.1 & 5.4 & 0 \\
\hline 7 & UT99-5, 50-150 & 8.5 & 26.8 & 36.6 & 1.4 & 5.6 & 7 & 0 \\
\hline 8 & UT99-4, 50-150 & 16.2 & 34.9 & 26.8 & 1.5 & 2.2 & 4 & 0.4 \\
\hline 9 & UT99-24, 50-150 & 1.6 & 19.7 & 47.5 & 4.9 & 4.9 & 1.6 & 1.6 \\
\hline 10 & UT99-16, 0-200 & 4.4 & 22.8 & 17.6 & 2.9 & 20.6 & 4.4 & 0 \\
\hline 11 & UT99-22, 0-150 & 2.2 & 40 & 24.4 & 4.4 & 17.8 & 4.4 & 0 \\
\hline 12 & UT99-23, 50-220 & 4.1 & 26.4 & 24.4 & 9.3 & 20.7 & 2.1 & 0 \\
\hline 13 & UT99-13, 50-125 & 3.6 & 7.2 & 21.6 & 0.9 & 55.9 & 0 & 0 \\
\hline 14 & UT99-20, 150-200 & 1.9 & 2.4 & 24.3 & 1.7 & 50.1 & 6.3 & 0.2 \\
\hline 15 & UT99-15, 150-200 & 5.8 & 10.8 & 21.5 & 0.3 & 26.5 & 10.5 & 0.3 \\
\hline 16 & UT99-13, 125-200 & 6.7 & 6.7 & 10.4 & 0.6 & 55.1 & 7.3 & 0 \\
\hline 17 & UT99-5, 150-200 & 10.7 & 4 & 18.1 & 1.9 & 40 & 5.9 & 0.4 \\
\hline 18 & UT99-4, 150-200 & 17.6 & 21.8 & 19.4 & 3.9 & 19.7 & 4.8 & 0 \\
\hline 19 & UT99-19, 150-200 & 5.6 & 2.4 & 42.4 & 0 & 4 & 24.8 & 0 \\
\hline 20 & UT99-24, 150-200 & 10.1 & 6.5 & 22.3 & 2.2 & 11.5 & 25.2 & 2.2 \\
\hline 21 & UT99-21, 150-300 & 8.3 & 1.7 & 22.7 & 0 & 9 & 40.7 & 0 \\
\hline 22 & UT99-22, 150-300 & 1.4 & 4.1 & 22.1 & 1.1 & 22.1 & 27 & 0 \\
\hline 23 & UT99-16, 200-300 & 7 & 6.7 & 21.4 & 0.3 & 16.6 & 30.5 & 0 \\
\hline 24 & UT99-5, 200-300 & 6.6 & 3.8 & 19.5 & 0 & 21.9 & 34.3 & 0 \\
\hline 25 & UT99-13, 200-400 & 13.7 & 5.4 & 12.6 & 0.9 & 27.7 & 30.2 & 0.9 \\
\hline 26 & UT99-19, 200-500 & 2.9 & 2.9 & 16.9 & 0.7 & 5.1 & 39 & 4.4 \\
\hline 27 & UT99-20, 200-500 & 4.6 & 1.9 & 20.2 & 0.5 & 4.6 & 42.2 & 3.5 \\
\hline 28 & UT99-15, 200-500 & 4.8 & 8.4 & 15.1 & 0 & 19.2 & 33.3 & 1.1 \\
\hline 29 & UT99-4, 200-500 & 3.1 & 6.3 & 23.3 & 1 & 20.1 & 34 & 3.1 \\
\hline 30 & UT99-24, 200-500 & 12.7 & 1.9 & 13.4 & 0 & 4.5 & 47.1 & 3.2 \\
\hline 31 & UT99-23, 220-500 & 14.5 & 3.8 & 10.6 & 2.1 & 20.4 & 30.6 & 0.9 \\
\hline 32 & UT99-16, 300-400 & 4.2 & 6.9 & 14.4 & 0.5 & 12 & 46.3 & 0 \\
\hline 33 & UT99-22, 300-500 & 1.9 & 5.4 & 14.6 & 0.3 & 8.3 & 49 & 3.8 \\
\hline 34 & UT99-21, 300-600 & 3.1 & 2.6 & 18.9 & 0 & 7.5 & 43 & 7 \\
\hline 35 & UT99-5, 300-600 & 15.9 & 1.9 & 14.8 & 0 & 16.4 & 35.8 & 1.3 \\
\hline 36 & UT99-13, 400-470 & 21.2 & 6.9 & 8.8 & 0 & 13.4 & 16.6 & 1.8 \\
\hline 37 & UT99-16, 400-700 & 7.2 & 2.8 & 9.7 & 0 & 7.8 & 28.9 & 6.4 \\
\hline 38 & UT99-22, 500-700 & 8.1 & 3.1 & 6.5 & 1.1 & 5.2 & 21.8 & 11.2 \\
\hline 39 & UT99-20, 500-800 & 7.3 & 2.4 & 6.2 & 0.8 & 11.8 & 19.1 & 14.8 \\
\hline 40 & UT99-19, 500-1000 & 11.3 & 4.9 & 4.9 & 1.9 & 7.1 & 14.6 & 12.9 \\
\hline 41 & UT99-15, 500-1000 & 5.1 & 4 & 5.4 & 1.1 & 9.3 & 20.7 & 7.1 \\
\hline 42 & UT99-4, 500-1000 & 8.8 & 2.3 & 3.7 & 0.5 & 7.6 & 17.4 & 10.6 \\
\hline 43 & UT99-24, 500-1000 & 21.5 & 1.2 & 2.6 & 0 & 2.4 & 10.6 & 20.6 \\
\hline 44 & UT99-23, 500-1000 & 8.4 & 4.5 & 4.7 & 0.3 & 4.2 & 17.6 & 22.1 \\
\hline 45 & UT99-21, 600-1000 & 4.7 & 2.2 & 6.7 & 0.3 & 7.8 & 22.5 & 3.3 \\
\hline 46 & UT99-16, 700-1000 & 8.1 & 3.9 & 9.7 & 1.3 & 4.5 & 15.9 & 3.6 \\
\hline 47 & UT99-22, 700-900 & 10.9 & 3 & 3.6 & 1.2 & 3.6 & 18.2 & 9.1 \\
\hline 48 & UT99-23, 1000-1300 & 8.6 & 3.7 & 3.7 & 0.7 & 5.1 & 10.8 & 3.4 \\
\hline
\end{tabular}

in the Southern Ocean, North Pacific, and Bering Sea (Petrushevskaya, 1968; Morley and Stepien, 1985; Abelmann and Gowing, 1997; Abelmann et al., 1999; Itaki et al., 2003). Besides the Spongodiscidae, we also found other species such as $C$. borealis, and the Plagoniidae group to occur occasionally in the surface-water layer (Fig. 4). However, as the radiolarian abundances in the surface waters are very low, not enough specimens in each sample were available to reach a statistically 
Table 5

Percentages of the dominant species in the summer plankton data set (LV stations)

\begin{tabular}{|c|c|c|c|c|c|c|c|c|}
\hline No. & Station, depth (m) & Plagoniidae & Spongodiscidae & C. borealis & Antarctissa sp. 1 & R. boreale & C. davisiana & D. hirundo \\
\hline 1 & LV28-14, 0-50 & 19.6 & 46.8 & 15.3 & 1.7 & 0.9 & 3.4 & 0 \\
\hline 2 & LV28-29, 0-50 & 17.8 & 11.4 & 23.3 & 17.4 & 4.1 & 5 & 0 \\
\hline 3 & LV28-7, 0-50 & 33 & 17.7 & 12.4 & 0 & 3.5 & 8.5 & 0.4 \\
\hline 4 & LV28-4, 0-50 & 28 & 10.3 & 5.7 & 11.4 & 1.1 & 7.4 & 0 \\
\hline 5 & LV28-40, 0-50 & 26.2 & 6.6 & 21.6 & 7.1 & 1.9 & 16.9 & 0.5 \\
\hline 6 & LV28-41, 0-50 & 19.1 & 40.4 & 10.6 & 4.3 & 12.8 & 0 & 0 \\
\hline 7 & LV28-42, 0-50 & 30.1 & 14.1 & 17.5 & 5.3 & 5.3 & 6.8 & 0 \\
\hline 8 & LV28-43, 0-50 & 48.2 & 16.4 & 8.2 & 5.5 & 0.9 & 0 & 0 \\
\hline 9 & LV28-44, 0-50 & 39.3 & 22.6 & 4.2 & 7.7 & 7.1 & 0.6 & 0 \\
\hline 10 & LV28-55, 0-50 & 12.8 & 38.9 & 2.8 & 15.6 & 5 & 0 & 0 \\
\hline 11 & LV28-3, 0-50 & 40.3 & 5 & 10.4 & 2.7 & 1.8 & 15.8 & 4.1 \\
\hline 12 & LV28-64, 0-50 & 14.2 & 55.5 & 12.3 & 4.5 & 1.9 & 6.5 & 0 \\
\hline 13 & LV28-66, 0-50 & 27.9 & 18.5 & 6 & 9.4 & 5.7 & 5.4 & 1.3 \\
\hline 14 & LV28-14, 50-100 & 8.2 & 34.9 & 32.9 & 8.2 & 2.1 & 1.4 & 0 \\
\hline 15 & LV28-29, 50-130 & 5.7 & 6.5 & 49.3 & 30.4 & 0.5 & 1.9 & 0.2 \\
\hline 16 & LV28-7, 50-130 & 11.3 & 9.4 & 43.4 & 20.8 & 1.9 & 5.7 & 0 \\
\hline 17 & LV28-4, 50-130 & 13.2 & 8.6 & 43.3 & 16.5 & 1.1 & 2.2 & 0 \\
\hline 18 & LV28-40, 50-130 & 22.3 & 3.2 & 26.9 & 38 & 0.5 & 1.6 & 0.4 \\
\hline 19 & LV28-41, 50-130 & 17.6 & 7.2 & 21.6 & 33.8 & 4.7 & 0.7 & 0 \\
\hline 20 & LV28-42, 50-130 & 22.7 & 4 & 13 & 24.7 & 10.6 & 0.4 & 0 \\
\hline 21 & LV28-43, 50-130 & 17.3 & 7.2 & 15.9 & 20.9 & 7.4 & 0.8 & 0 \\
\hline 22 & LV28-44, 50-130 & 20.6 & 4.2 & 4.5 & 23.2 & 12.9 & 0.3 & 0 \\
\hline 23 & LV28-55, 50-130 & 5.6 & 2.5 & 2 & 27.4 & 34.4 & 0.3 & 0 \\
\hline 24 & LV28-3, 50-130 & 19.6 & 10.9 & 38.4 & 9.8 & 1.8 & 6.9 & 0 \\
\hline 25 & LV28-64, 50-130 & 4.3 & 5 & 15.8 & 53.8 & 10.2 & 0.7 & 0 \\
\hline 26 & LV28-66, 50-130 & 15 & 6.1 & 5.3 & 36.9 & 18.3 & 0.5 & 0.3 \\
\hline 27 & LV28-14, 100-150 & 18.4 & 14.1 & 38 & 13.8 & 6.9 & 2.9 & 0 \\
\hline 28 & LV28-14, 150-200 & 25.3 & 12.1 & 26.3 & 9.6 & 7.1 & 6.1 & 0 \\
\hline 29 & LV28-29, 130-200 & 7.6 & 2.6 & 52.3 & 18.1 & 7 & 6.1 & 0 \\
\hline 30 & LV28-7, 130-200 & 24.4 & 5.8 & 29.4 & 8.3 & 8.3 & 3.5 & 0 \\
\hline 31 & LV28-4, 130-200 & 20.2 & 5.6 & 37.7 & 7.4 & 7.8 & 4.8 & 0 \\
\hline 32 & LV28-40, 130-200 & 36.7 & 4.6 & 28.1 & 10.2 & 2.3 & 4.2 & 0 \\
\hline 33 & LV28-41, 130-200 & 30.4 & 3.5 & 16.4 & 18 & 11.3 & 1.8 & 0.2 \\
\hline 34 & LV28-42, 130-200 & 14.1 & 8.5 & 14.6 & 13 & 32.4 & 2.7 & 0 \\
\hline 35 & LV28-43, 130-200 & 9.4 & 4.4 & 10.5 & 15.4 & 41.6 & 0.8 & 0 \\
\hline 36 & LV28-44, 130-200 & 21.7 & 3.5 & 10.9 & 11.7 & 27.4 & 2.4 & 0 \\
\hline 37 & LV28-55, 130-200 & 12.5 & 3.6 & 4.1 & 16.3 & 47.2 & 0.6 & 0 \\
\hline 38 & LV28-3, 130-200 & 22.3 & 7.4 & 40.5 & 7.8 & 4.5 & 5.5 & 0 \\
\hline 39 & LV28-64, 130-200 & 12.8 & 9.2 & 29.7 & 16.6 & 16.9 & 2 & 0 \\
\hline 40 & LV28-66, 130-200 & 32.6 & 6 & 12 & 20.5 & 12.9 & 3.9 & 0 \\
\hline 41 & LV28-14, 200-400 & 35.5 & 5.6 & 19.8 & 2.7 & 3.8 & 17.8 & 0.6 \\
\hline 42 & LV28-29, 200-500 & 5.8 & 3.2 & 30.4 & 1.4 & 5.2 & 36.2 & 0.3 \\
\hline 43 & LV28-7, 200-300 & 29.7 & 2 & 23.6 & 5.4 & 6.1 & 18.2 & 0 \\
\hline 44 & LV28-4, 200-300 & 37.8 & 3.5 & 22.6 & 5.4 & 1.9 & 9.8 & 0 \\
\hline 45 & LV28-43, 200-300 & 38.6 & 3.3 & 15.8 & 5.2 & 5.4 & 9.5 & 0 \\
\hline 46 & LV28-44, 200-300 & 54.3 & 4.8 & 7.5 & 4.3 & 3.4 & 10.3 & 0 \\
\hline 48 & LV28-4, 300-500 & 35.5 & 2.5 & 14.7 & 1.8 & 2.2 & 23 & 0.6 \\
\hline 47 & LV28-7, 300-500 & 18.6 & 1.2 & 18.6 & 2.5 & 2.5 & 37.5 & 0 \\
\hline 49 & LV28-40, 200-500 & 24.2 & 1.9 & 19.2 & 2.5 & 2.1 & 27.3 & 0.4 \\
\hline 50 & LV28-41, 200-500 & 24.9 & 2.5 & 18.7 & 2.7 & 1.7 & 23.7 & 0.2 \\
\hline 51 & LV28-42, 200-500 & 31.3 & 3.8 & 25.1 & 1.1 & 1.7 & 17.5 & 0 \\
\hline 52 & LV28-43, 300-500 & 26.2 & 2.8 & 18.9 & 1.7 & 1 & 16.4 & 0.3 \\
\hline 53 & LV28-44, 300-500 & 41.2 & 2.7 & 21.3 & 1.3 & 1.6 & 19.1 & 0.3 \\
\hline 54 & LV28-55, 200-500 & 28.3 & 4.7 & 21.2 & 9.7 & 5.9 & 11.1 & 0 \\
\hline 55 & LV28-3, 200-500 & 32.8 & 2.4 & 13.8 & 2.8 & 3.2 & 25.1 & 0 \\
\hline 56 & LV28-64, 200-500 & 19.3 & 2.2 & 31.6 & 2.5 & 2.7 & 29.4 & 0 \\
\hline 57 & LV28-66, 200-500 & 40.4 & 0.8 & 13.7 & 4.3 & 2.4 & 24.7 & 0 \\
\hline
\end{tabular}


Table 5 (continued)

\begin{tabular}{|c|c|c|c|c|c|c|c|c|}
\hline No. & Station, depth (m) & Plagoniidae & Spongodiscidae & C. borealis & Antarctissa sp. 1 & $R$. boreale & C. davisiana & D. hirundo \\
\hline 58 & LV28-29, 500-1000 & 9.4 & 1.4 & 12.2 & 0 & 2.4 & 14.4 & 30.1 \\
\hline 59 & LV28-40, 500-1000 & 26.9 & 1.4 & 5.7 & 0.3 & 2.8 & 8.9 & 25.2 \\
\hline 60 & LV28-41, 500-1000 & 12.5 & 1.5 & 9 & 0.8 & 1.9 & 7.7 & 29.3 \\
\hline 61 & LV28-42, 500-900 & 16.4 & 0.7 & 8.4 & 0.7 & 1.8 & 13.8 & 19.6 \\
\hline 62 & LV28-55, 500-1000 & 14.9 & 2 & 14.9 & 1.6 & 1.6 & 12.4 & 17.7 \\
\hline 63 & LV28-3, 500-1000 & 34.8 & 0.9 & 5.6 & 0.5 & 1.3 & 7.1 & 18.3 \\
\hline 64 & LV28-64, 500-1000 & 30.8 & 2.6 & 6.5 & 0.5 & 2.1 & 10.4 & 24.9 \\
\hline 65 & LV28-66, 500-1000 & 28.3 & 1.5 & 6.5 & 0.7 & 1.2 & 9 & 22.1 \\
\hline
\end{tabular}
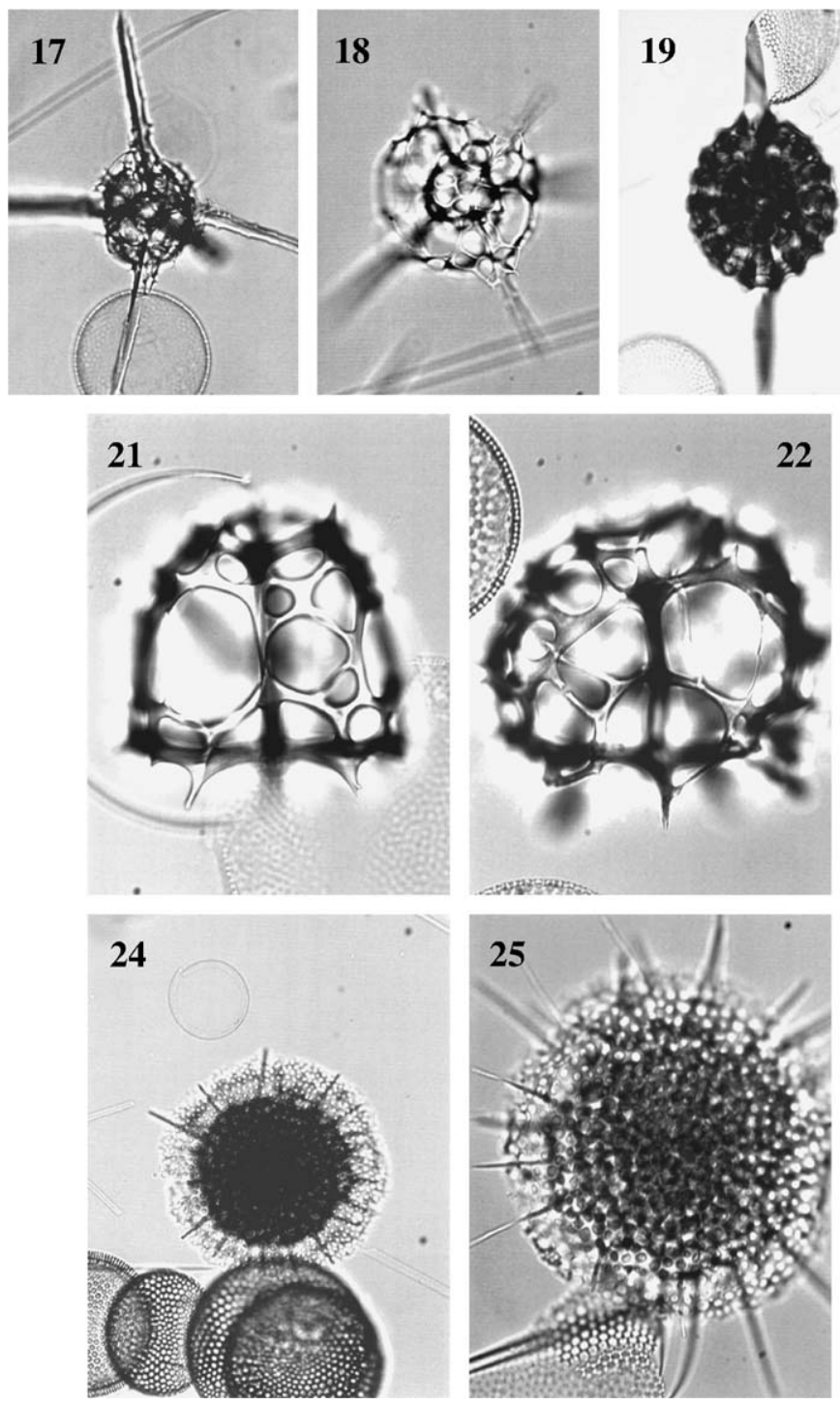
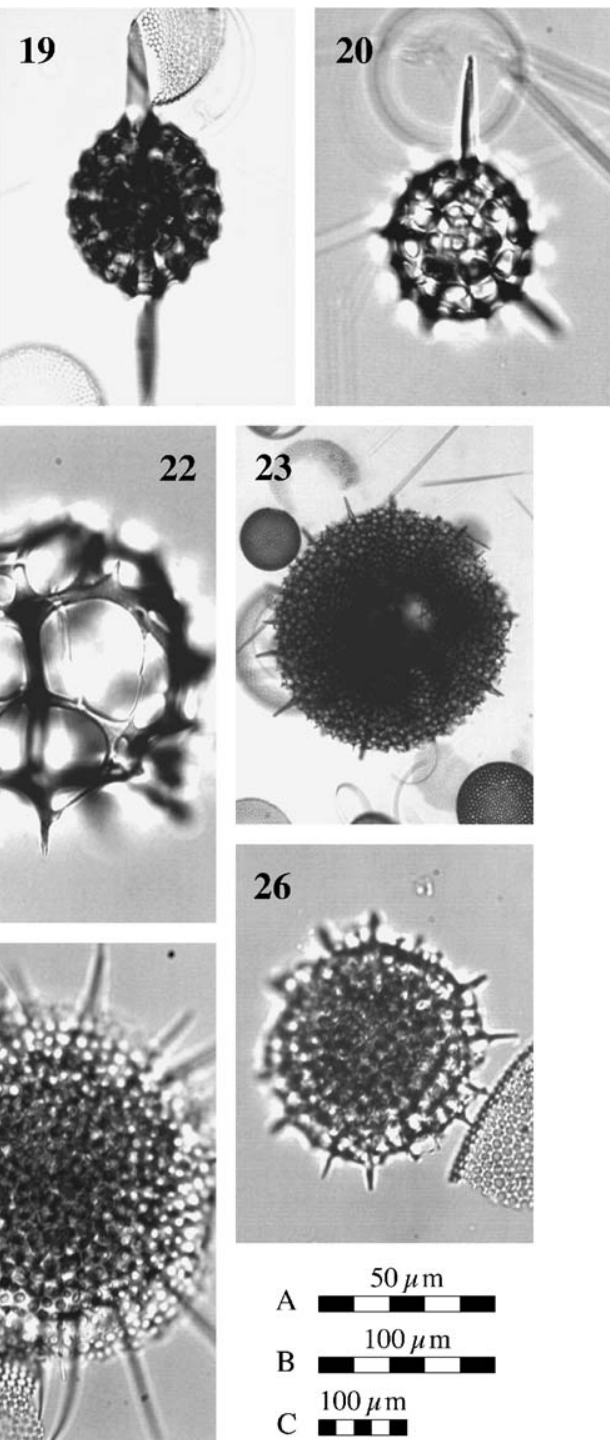

Fig. 7. Radiolarians from surface sediments of the Sea of Okhotsk. Scale bar A is for photographs 1-14, 18, 20-22, and 25-26; scale bar B is for photographs 15-17, 19, and 24; and scale bar C is for photograph 23. (7.17) Rhizoplegma boreale (LV28-2-2), (7.18) Rhizoplegma boreale (LV28-34-1), (7.19) Stylatractus (?) pyriformis (LV28-2-2), (7.20) Stylatractus (?) pyriformis, juvenile specimen (LV28-2-2), (7.21) Ceratospyris borealis (LV28-34-1), (7.22) Ceratospyris borealis (LV28-2-2), (7.23) Spongotrochus glacialis (LV28-34-1), (7.24) Stylochlamydium venustum (LV28-34-1), (7.25) Stylochlamydium venustum (LV28-2-2), (7.26) Stylochlamydium venustum, juvenile specimen (LV28-2-2). 
significant amount. This especially concerns the spring samples. For this reason, we eliminated some spring surface-water stations for the percentage calculations (Fig. 4; Table 4). For the latitudinal distribution, we grouped all species of $S$. glacialis and $S$. venustum as Spongodiscidae and only illustrate the standing stock data during summer and spring. Considering that in the surface-sediment record $S$. venustum clearly dominates the Spongodiscidae, we compared the distribution pattern of the species in surface sediments with that of the Spongodiscidae in the plankton (Fig. 8).

The relative abundance pattern of $S$. venustum in SOk surface sediments clearly shows its dominance in the eastern part of the SOk, which is strongly influenced by the Kamchatka Current, leading to open-ocean conditions during winter, except for very cold years (Fig. 8). An abundance increase in this area is also documented in the accumulation rates of $S$. venustum in surface sediments and summer standing stocks of the Spongodiscidae, although these values are very low. Hays and Morley (2003) reported maximum flux rates of $S$. venustum during spring (April-June) in the northeastern part of the SOk. The spring plankton samples for this study were taken between the end of May and mid of June. As the spring values of $S$. venustum are very low, we expect that we have missed its productivity maximum that year. The spring maximum of $S$. venustum recorded from the northeastern SOk (Hays and Morley, 2003) occurs synchronously to the diatom production peak (Broerse et al., 2000). In contrast to other
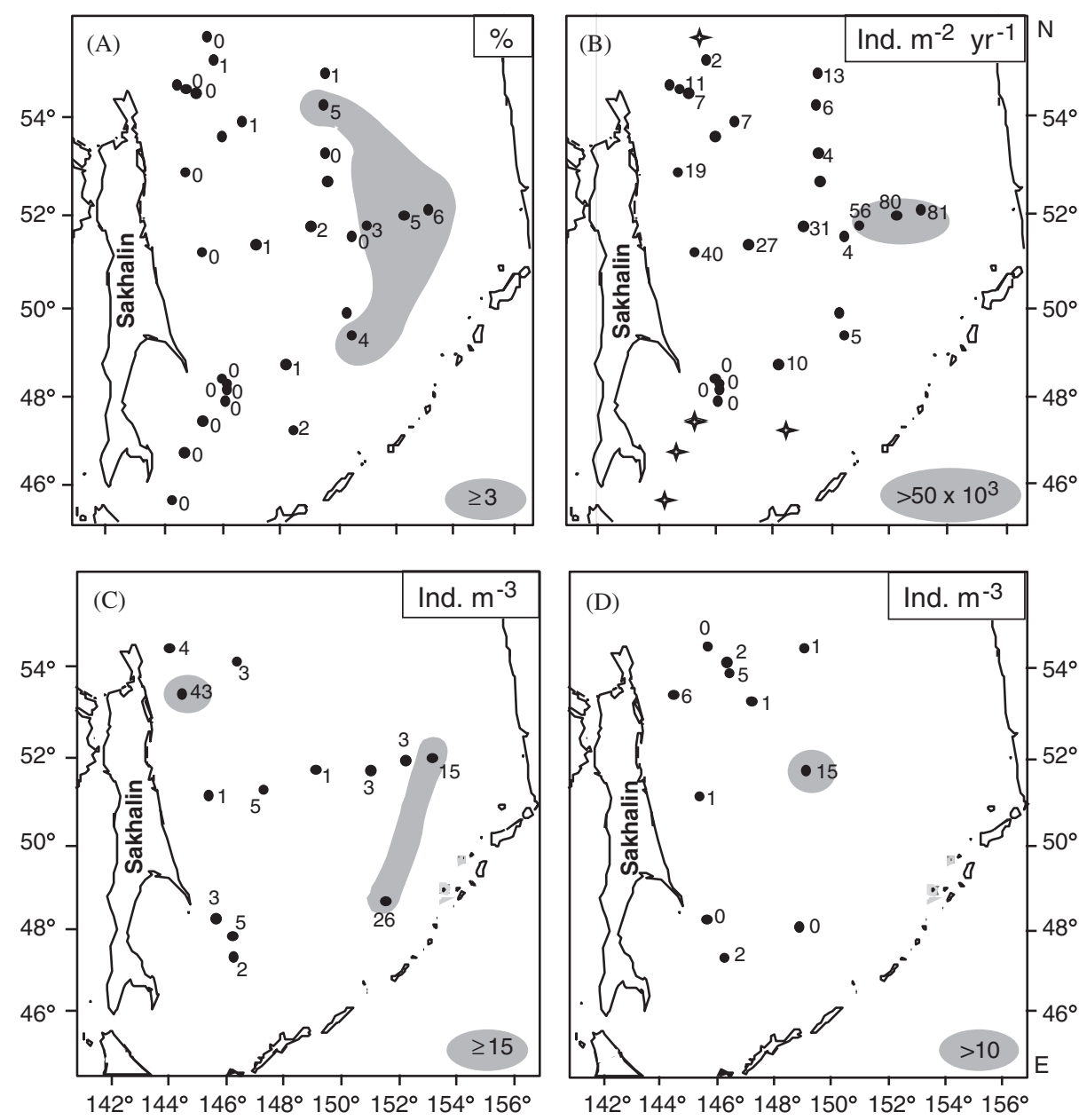

Fig. 8. Comparison of (A) relative abundances and (B) accumulation rates of Stylochlamydium venustum in surface sediments, with (C) summer and (D) spring standing stocks of Spongodiscidae group in the upper sea surface $(50 \mathrm{~m})$. Stations are marked with an asterisk where RAR could not be estimated due to lacking age assignment. 
deep-living nassellarians, $S$. venustum, a larger spumellarian, has a herbivor or omnivor feeding behavior (Anderson, 1983; Anderson et al., 1989). The co-occurrence of $S$. venustum and diatom peaks during spring leads us to conclude that $S$. venustum is directly related to the phytoplankton production at the sea surface, where it mainly feeds on diatoms. This might also explain why $S$. venustum is not a prominent species of the Arctic Ocean (Bjørklund and Kruglikova, 2003) where the summer seasons are very short and productivity is low. The juvenile status of most specimens in the plankton, and the observed very low concentrations in both plankton and surface sediments, indicate that even this species does not find optimal conditions in SOk surface waters today. Increasing numbers of $S$. venustum therefore might indicate more stable conditions at the sea surface in the geological past, characterized by less pronounced seasonal changes combined with an increased seasonal phytoplankton production.

\subsection{SODL assemblage}

The water layer between 50 and $200 \mathrm{~m}$, the SODL, is characterized by a near-freezing temperature minimum, with temperatures ranging between -1.7 and $+1{ }^{\circ} \mathrm{C}$ (Kitani, 1973; Yang and Honjo, 1996). Most dominant species in this water mass are Ceratospyris borealis, Antarctissa (?) sp. 1, and Rhizoplegma boreale (Fig. 4, Tables 2-5). Each of these species inhabits different depth intervals that may be either ascribed to different temperature relations and feeding behaviors or rivalry between species, which share the same ecological niche.

C. borealis is dominant in the SODL but it extends in higher numbers down to $500 \mathrm{~m}$ (Figs. 4 and 7.21-7.22; Tables 4 and 5). The depth range of $50-500 \mathrm{~m}$ is in accordance with sediment trap data from the SOk, where $C$. borealis was encountered in shallow and deep traps, deployed at 258 and $1061 \mathrm{~m}$, respectively (Hays and Morley, 2003; Okazaki et al., 2003) and with plankton studies from the Japan Sea where the species was found in a water depth between 80 and $300 \mathrm{~m}$ (Itaki, 2003). $C$. borealis is a common member of the radiolarian assemblage in the subarctic North Pacific (Takahashi, 1997), and it also occurs in the Bering Sea (Ling et al., 1971; Takahashi et al., 2002), but it has not yet been described from the Arctic Ocean (Bjørklund and Kruglikova, 2003; Itaki et al., 2003). In the SOk, the highest standing stock of $C$. borealis occurs during late summer close to Sakhalin, whereas the standing stock is one magnitude lower during spring (Fig. 9). A late summer dominance is consistent with sediment trap observations showing that the maximum flux of $C$. borealis occurs between August and October (Hays and Morley, 2003; Okazaki et al., 2003). Other than in the SOk, where the $C$. borealis flux is decoupled from the diatom flux, the C. borealis flux in eastern subarctic North Pacific occurs synchronously with the diatom flux of Neodenticulata seminae, the latter accounting for more than $70 \%$ of the diatom assemblages (Takahashi, 1997). Based on the close relation between the fluxes of $C$. borealis and $N$. seminae and the close correlation of the latter to organic carbon and total mass fluxes, $C$. borealis is considered to be indicative for high productivity in the eastern subarctic Pacific (Takahashi, 1997). The coupling and decoupling of C. borealis to the diatom flux reported from the eastern subarctic Pacific and SOk as well as its relatively large depth range in the water column of the SOk (Fig. 4) might point to an opportunistic behavior. Depending on the kind of food supply and rivalry with other small zooplankton grazers, it might move in the water column from the subsurface to intermediate depths feeding on detritus and bacteria.

The high summer standing stock pattern close to Sakhalin is well mirrored in the accumulation rates of C. borealis in SOk surface sediments (Fig. 9). However, relative abundances of the species in surface sediments show a different pattern than its accumulation rates and absolute and relative abundances in the plankton. The enrichment of $C$. borealis in surface sediments of the northern part of the SOk might be attributed to minor dilution processes of the radiolarian assemblage, evoked by the highly productive Plagoniidae group that strongly affects the radiolarian composition close to the Sakhalin shelf area (Fig. 5).

More restricted to the SODL is Antarctissa (?) sp. 1, which exhibits highest abundances in the temperature minimum of the SODL between 50 and $150 \mathrm{~m}$ (Figs. 4 and 6.1-6.2; Tables 4 and 5). Antarctissa (?) sp. 1 has been described by Nimmergut and Abelmann (2002) as a new species of the genus Antarctissa, although the genus affiliation is somewhat difficult because many specimens are juveniles without fully developed skeletons and the available criteria for the attribution of radiolarians into the genus Antarctissa are not precisely defined. The high amount of small-sized juveniles of 

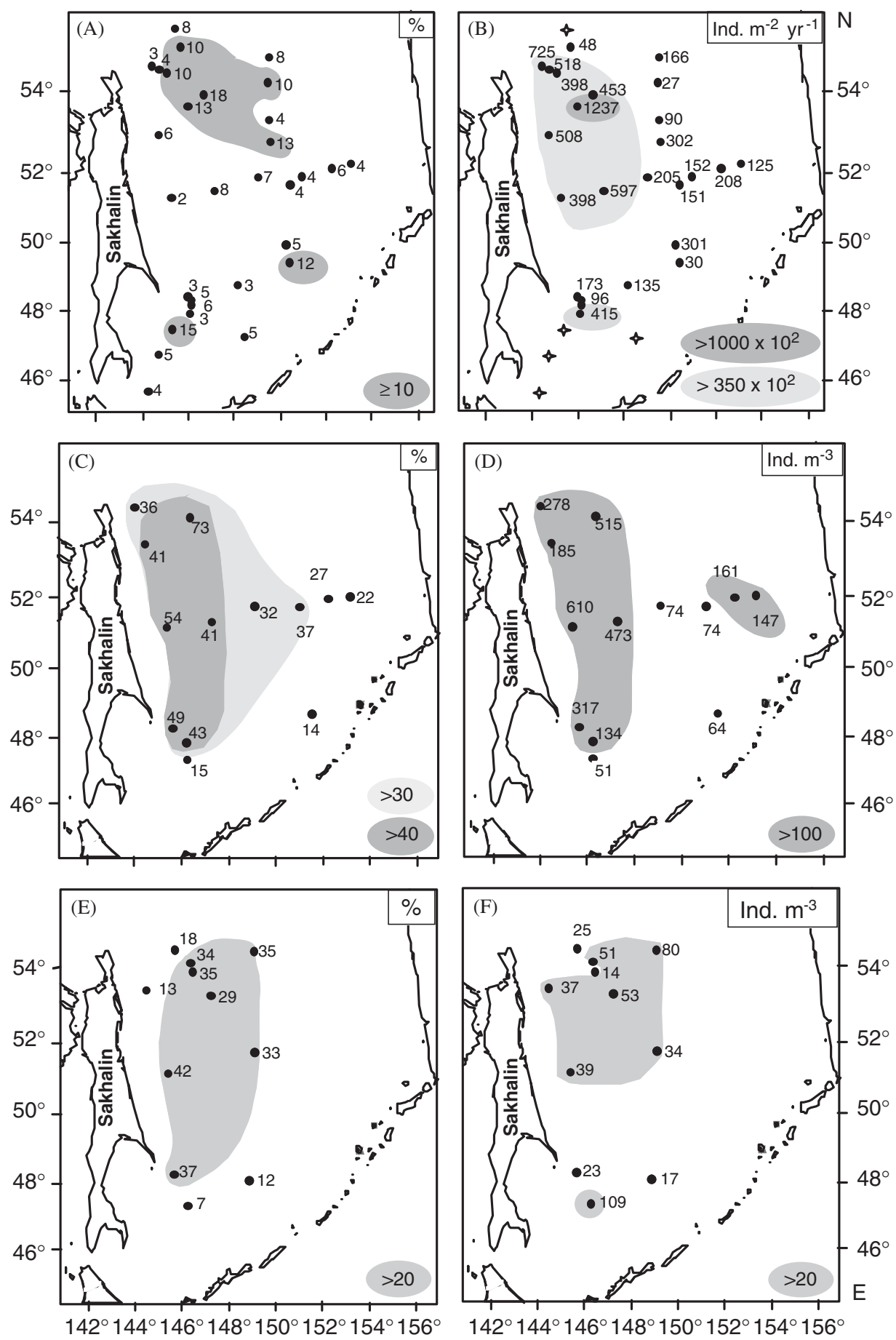

Fig. 9. Comparison of the distribution pattern of Ceratospyris borealis in surface sediments with its latitudinal distribution in the water depth layer 50-500 m. Indicated are (A) relative abundances and (B) accumulation rates in surface sediments, (C) relative abundances, and (D) standing stocks during summer, (E) relative abundances, and (F) standing stocks during spring. Stations are marked with an asterisk where RAR could not be estimated due to lacking age assignment.

Antarctissa (?) sp. 1 might be one reason why it is not documented in the sediment trap data of the SOk (Hays and Morley, 2003; Okazaki et al., 2003), as these studies only consider the size fraction $>63 \mu \mathrm{m}$. Abundant Antarctissa (?) sp. 1 exclusively occurs in the summer plankton, and highest 
standing stock and relative abundances have been observed in the western part of the SOk (Fig. 10). The distribution of Antarctissa (?) sp. 1 in the plankton is well correlated with its abundance pattern in surface sediments (Fig. 10). The western part of the SOk is stronger affected by sea ice than the southeastern part where the influence of the "warm" Kamchatka Current generally leads to open-ocean conditions during winter. Thus, the extended sea-ice cover during winter in the western part of the SOk favors the pronounced generation of the SODL during summer in this area. We assume that the temperature minimum zone of the SODL represents an ecological niche for a species
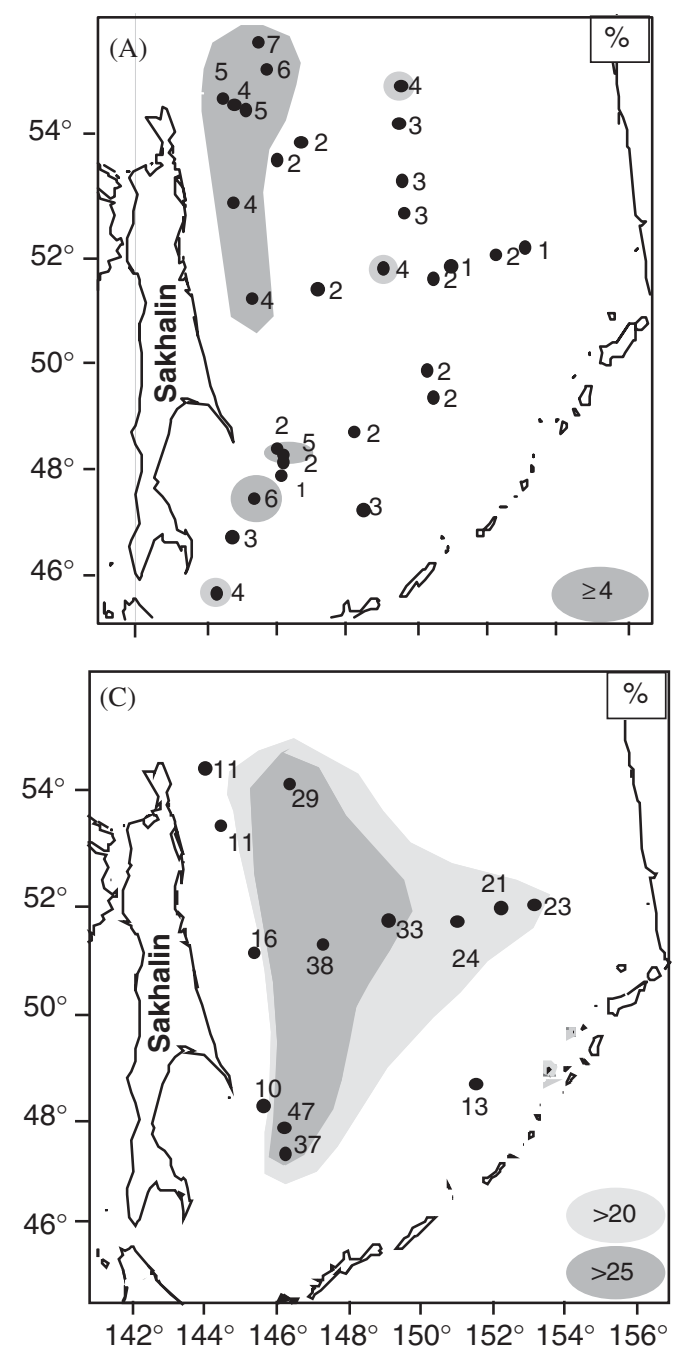

such as Antarctissa (?) sp. 1, which prefers a subsurface cold-water environment and feeds on bacteria or relatively fresh phytodetritus originated from the highly productive sea surface.

$R$. boreale inhabits mainly the depth interval directly below the temperature minimum of the SODL between 150 and $200 \mathrm{~m}$ (Figs. 4 and 7.17-7.18; Tables 4 and 5). $R$. boreale is a widespread species in cold-water environments of northern and southern high-latitude ocean areas (Petrushevskaya, 1968; Abelmann, 1992a, b; Itaki and Takahashi, 1995; Abelmann and Gowing, 1997; Schröder-Ritzrau, 1995; Nishimura et al., 1997; Bjørklund et al., 1998; Dolven and Bjørklund,
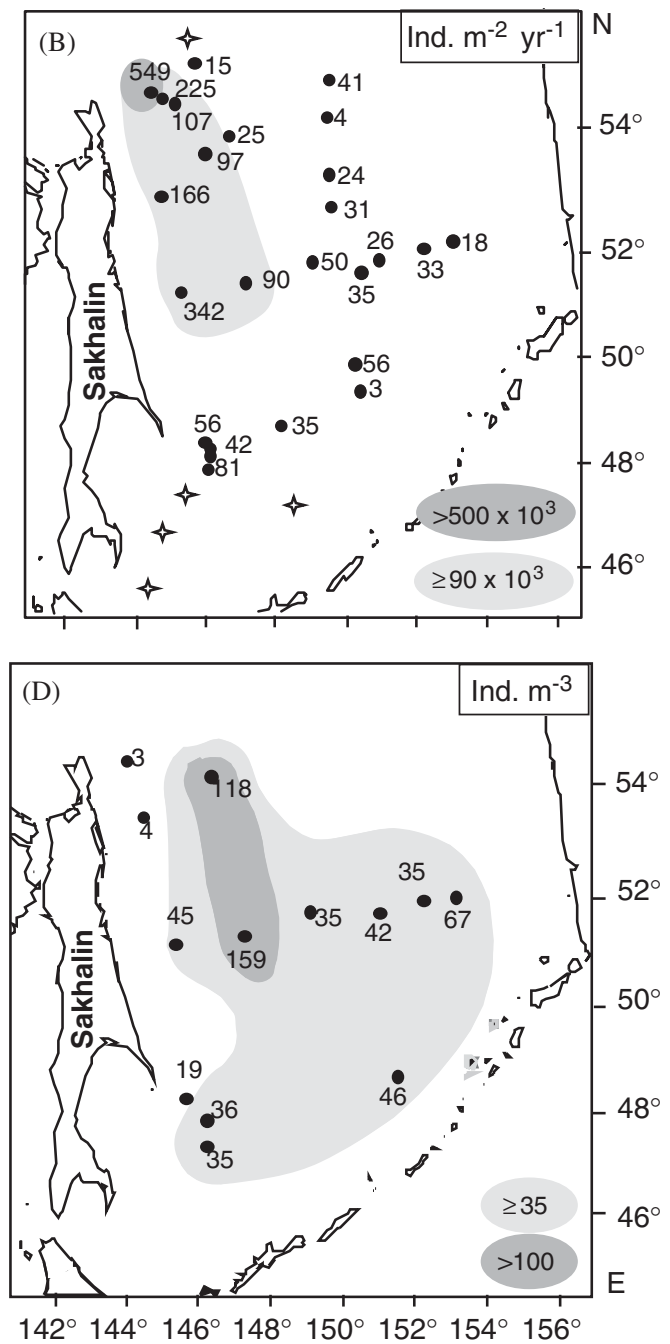

Fig. 10. Comparison of the distribution pattern of Antarctissa (?) sp. 1 in surface sediments with its latitudinal distribution in the temperature minimum layer of the Sea of Okhotsk Dicothermal Layer (SODL) that occurs in 50-150 m water depth. Indicated are (A) relative abundances and (B) accumulation rates in surface sediments, (C) relative abundances, and (D) standing stocks during summer. Stations are marked with an asterisk where RAR could not be estimated due to lacking age assignment. 
2001). In the SOk, its seasonal distribution pattern is rather diverse. Maximum standing stock of the species occurs during summer in the southeastern part of the SOk, extending in lower amounts in a band to the northwestern area (Fig. 11). The dominance of the species in the southeastern part
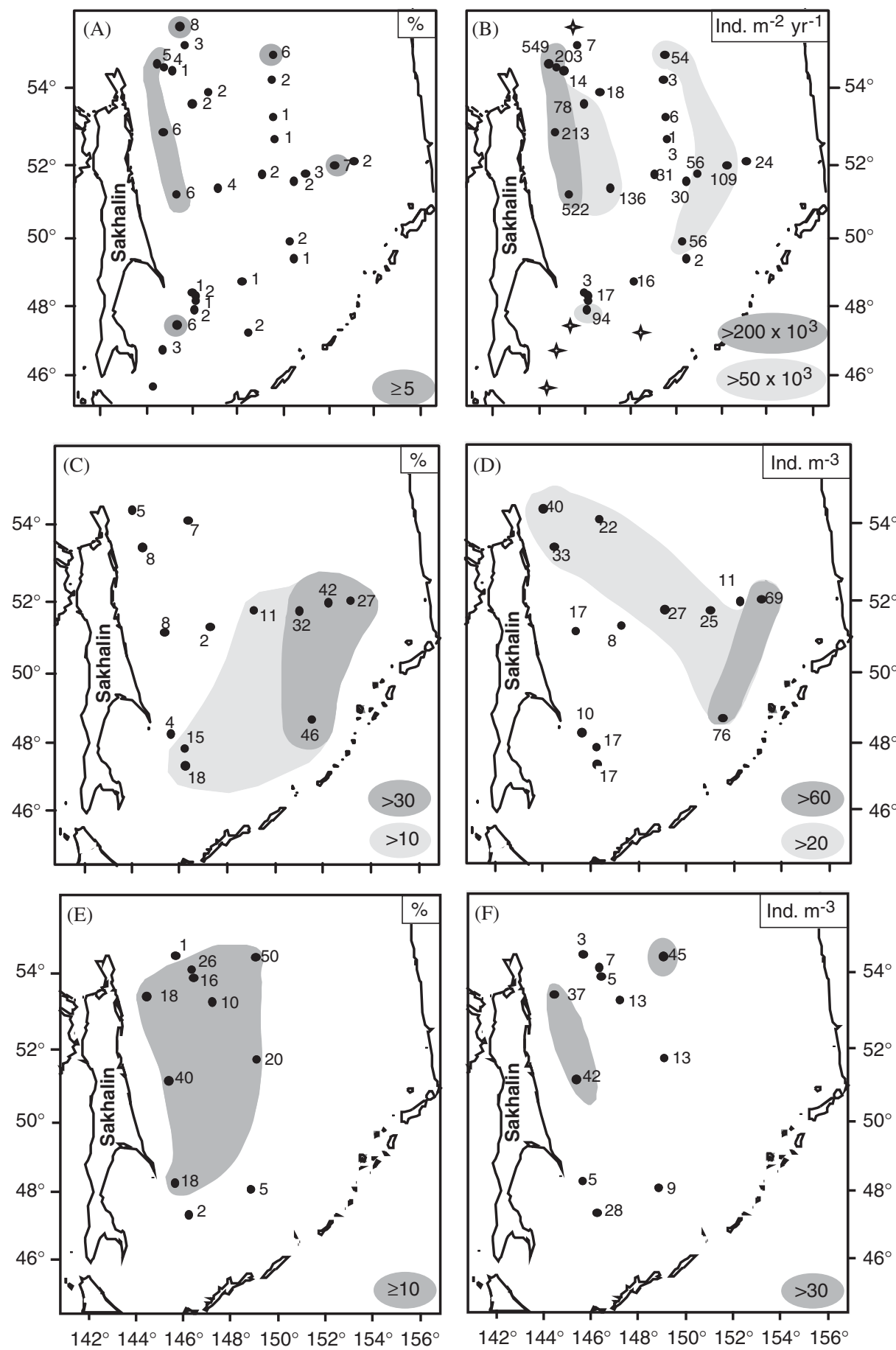

Fig. 11. Comparison of the distribution pattern of Rhizoplegma boreale in surface sediments with its latitudinal distribution in a water layer that occurs in 150-200 $\mathrm{m}$ water depth below the temperature minimum in the SODL. Indicated are (A) relative abundances and (B) accumulation rates in surface sediments, (C) relative abundances, and (D) standing stocks during summer, (E) relative abundances, and (F) standing stocks during spring. Stations are marked with an asterisk where RAR could not be estimated due to lacking age assignment. 
of the SOk during summer also is shown in its relative abundances (Fig. 11). However, other than in summer, $R$. boreale prevails in the eastern part of the SOk during spring. These seasonal differences are reflected in the accumulation of $R$. boreale in SOk surface sediments where the species exhibits highest numbers in the eastern and western part, respectively (Fig. 11). The relative abundance pattern in surface sediments further indicates a slight increase of the species close to the shelf areas. Similar seasonal differences also are recorded from shallow sediment trap data of the northeastern (Hays and Morley, 2003) and western part of the SOk (Okazaki et al., 2003). These data show that in the northwestern part of the SOk maximum fluxes of $R$. boreale occur during fall, whereas in the eastern part highest fluxes were reported from the spring season.

The data indicate that $R$. boreale is restricted to subsurface depth in the SOk and that it seasonally changes its latitudinal distribution. We conclude from these data that $R$. boreale, comparable to $C$. borealis, has an opportunistic behavior, only differing in the way that the latter form migrates in the water column, extending its depth habitat, whereas $R$. boreale migrates latitudinally, staying in the same depth layer. The environmental conditions forcing these distribution patterns are not well known. However, it can be speculated that the species follow specific survival and feeding strategies, inhabiting specific ecological niches. It can thus be concluded that Antarctissa (?) sp. 1 is the sole taxon closely related to the presence of the SODL, and might be indicative for the existence of a pronounced summer sea-surface stratification.

\subsection{SOIW assemblage}

The most prominent species in the SOIW (200-1000 m) are Cycladophora davisiana and Dictyophimus hirundo, although other species such as $C$. borealis and the Plagoniidae group extend into this water mass (Figs. 4 and 6.13-6.14; Tables 4 and 5).

C. davisiana has its main distribution in the upper SOIW (200-500 m) (Fig. 12). This indicates that the specific hydrographic conditions in the upper SOIW are controlling the occurrence of $C$. davisiana in this water depth. The cold and well-oxygenated SOIW is strongly influenced by dense shelf-derived water that is formed during sea-ice formation on the shelf (Wong et al., 1998). The main areas of SOIW formation with the coldest temperatures are in the northern part of the SOk where the development of large polynias during winter leads to extensive shelf water formation (Kitani, 1973; Wong et al., 1998). The close affinity of the species to the SOIW properties also is reflected in the relative abundance distribution of the species in SOk surface sediments (Fig. 13). High percentages of $C$. davisiana occur in the northern central part of the SOk, the main source area for the formation of SOIW, and also the C. davisiana maximum in the southern part off the Sakhalin shelf is confined to a region characterized by intensive sea-ice formation and production of cold shelf water (Kitani, 1973). A similar relation of C. davisiana to this specific kind of water-mass properties is reported from the Japan Sea. $C$. davisiana dominates the radiolarian assemblage of the Japan Sea Proper Water (JSPW) between 1000 and $2000 \mathrm{~m}$, a water mass with properties similar to those of the SOIW (Itaki, 2003). The main difference between the occurrence of $C$. davisiana in the Japan Sea and SOk is in the $C$. davisiana standing stock values, which are very low in the JSPW $\left(<1 \mathrm{~m}^{-3}\right)$ but high in the SOIW (up to $370 \mathrm{~m}^{-3}$ ) (Figs. 12 and 13; Nimmergut and Abelmann, 2002; Itaki, 2003). In the SOk, maximum standing stocks of the species occur in the vicinity of Sakhalin, an area where enhanced phytoplankton production also occurs during summer (Fig. 13). This pattern is reflected in the accumulations rates of $C$. davisiana in SOk surface sediments, which exhibit highest values in this area (Fig. 13). $C$. davisiana is a small deep-living radiolarian, which feeds on phytodetritus from the highly productive sea surface or/and on bacteria attached to sinking organic matter (Anderson, 1983; Anderson et al., 1989). The high $C$. davisiana numbers in the SOk plankton and surface sediments as well as the high bacteria biomass in deeper water layers (Sorokin and Sorokin, 1999) point to enhanced export of organic matter to mesopelagic depth.

The high radiolarian standing stock values at a depth below $200 \mathrm{~m}$ during summer (Figs. 12 and 13; Nimmergut and Abelmann, 2002) are in agreement with the findings of Hays and Morley (2003). These authors recently concluded from a Bering Sea/SOk comparison that the SOk must have deeper levels of carbon consumption and regeneration than the Bering Sea, because the summer biomass in the Bering Sea is mainly epipelagic and that of the SOk mainly mesopelagic. Our data are in accordance with the conclusion of Hays and Morley (2003) that C. davisiana is an indicator for a mesopelagic 


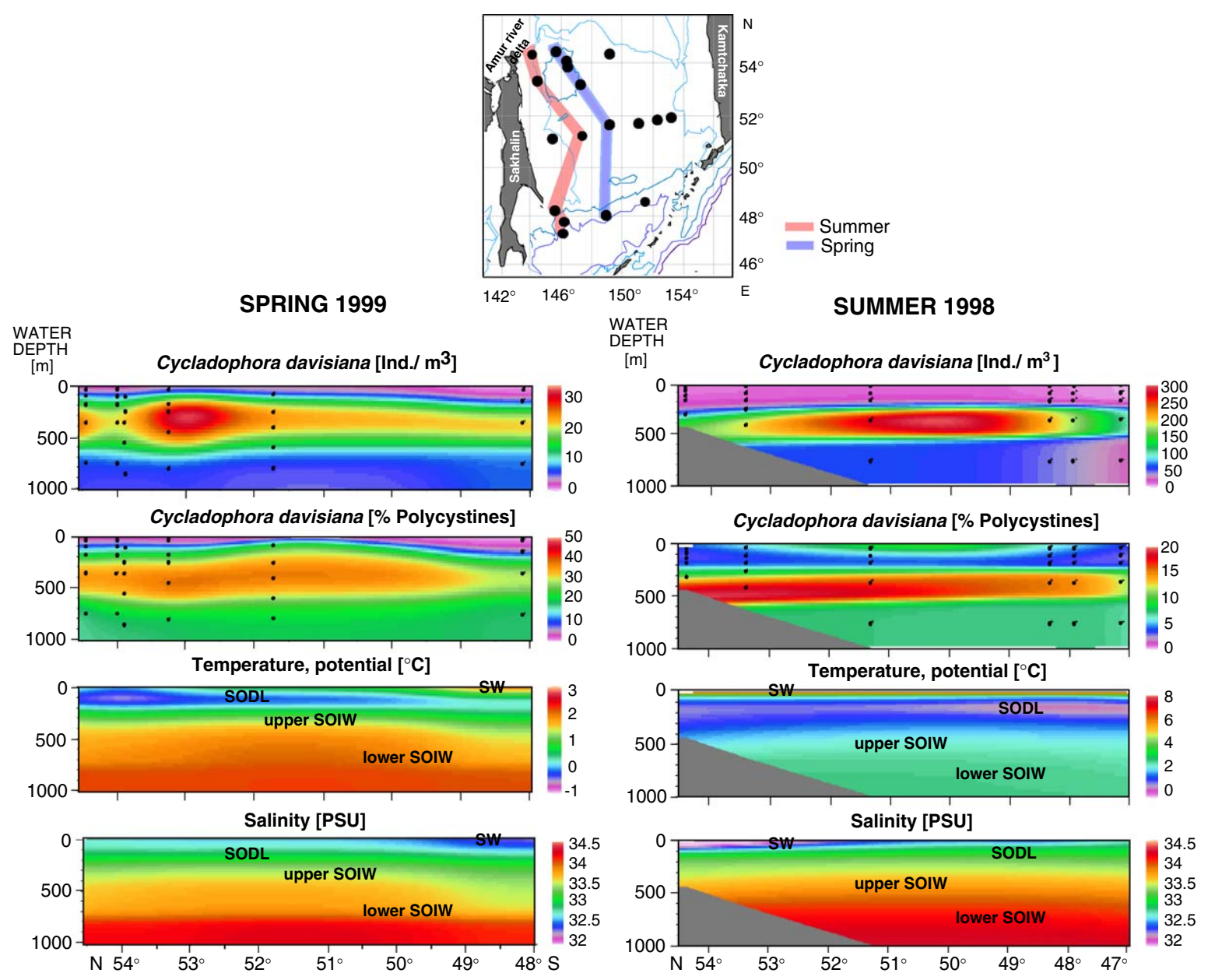

Fig. 12. Standing stock and percent abundance of Cycladophora davisiana and its relation to the hydrographic structure of the upper $1000 \mathrm{~m}$ of the SOk during spring and summer. The plankton sampling was undertaken according to the water-mass structure received from hydrographic data, which have been measured at each station (Winkler et al., 1999; Sosnin and Salyuk, unpubl. data). T, temperature; $S$, salinity; SW, surface water; SODL, SOk Dicothermal Layer; SOIW, SOk Intermediate Water.

productivity regime leading to carbon consumption and regeneration at deeper levels. However, our data are not in agreement with their statements that the relative abundances of $C$. davisiana alone can be used as a proxy to reconstruct such a productivity regime and further that the species is an indicator for a stable sea-surface stratification, as already proposed by the authors earlier (Morley and Hays, 1983).

Our data and those from the Japan Sea show that the relative abundances of $C$. davisiana provide primarily information on the water-mass properties of intermediate and deep-water masses, while absolute abundances provide insight into the past productivity regime. The high percentages of $C$. davisiana in the Japan Sea Bottom Water $(>70 \%)$ as well as its increased numbers in a deep sediment trap located in the California upwelling regime and in a core located in the Benguela Upwelling system are not in relation to any pronounced sea-surface stratification (Welling et al., 1992; Jacot des Combes and Abelmann, submitted). The increased numbers of $C$. davisiana reported from both upwelling regimes can be related to the inflow of cold intermediate waters originated from the subarctic Pacific and the Southern Ocean, respectively. Upwelling areas are highly productive areas with high export of organic matter to the deep ocean but, as long as the deeper water masses are relatively warm, $C$. davisiana is a minor component of the radiolarian assemblage in these areas. With the inflow of cold intermediate/deep waters the two factors described from the SOk, (1) high export of organic matter to mesopelagic depth, and (2) the 

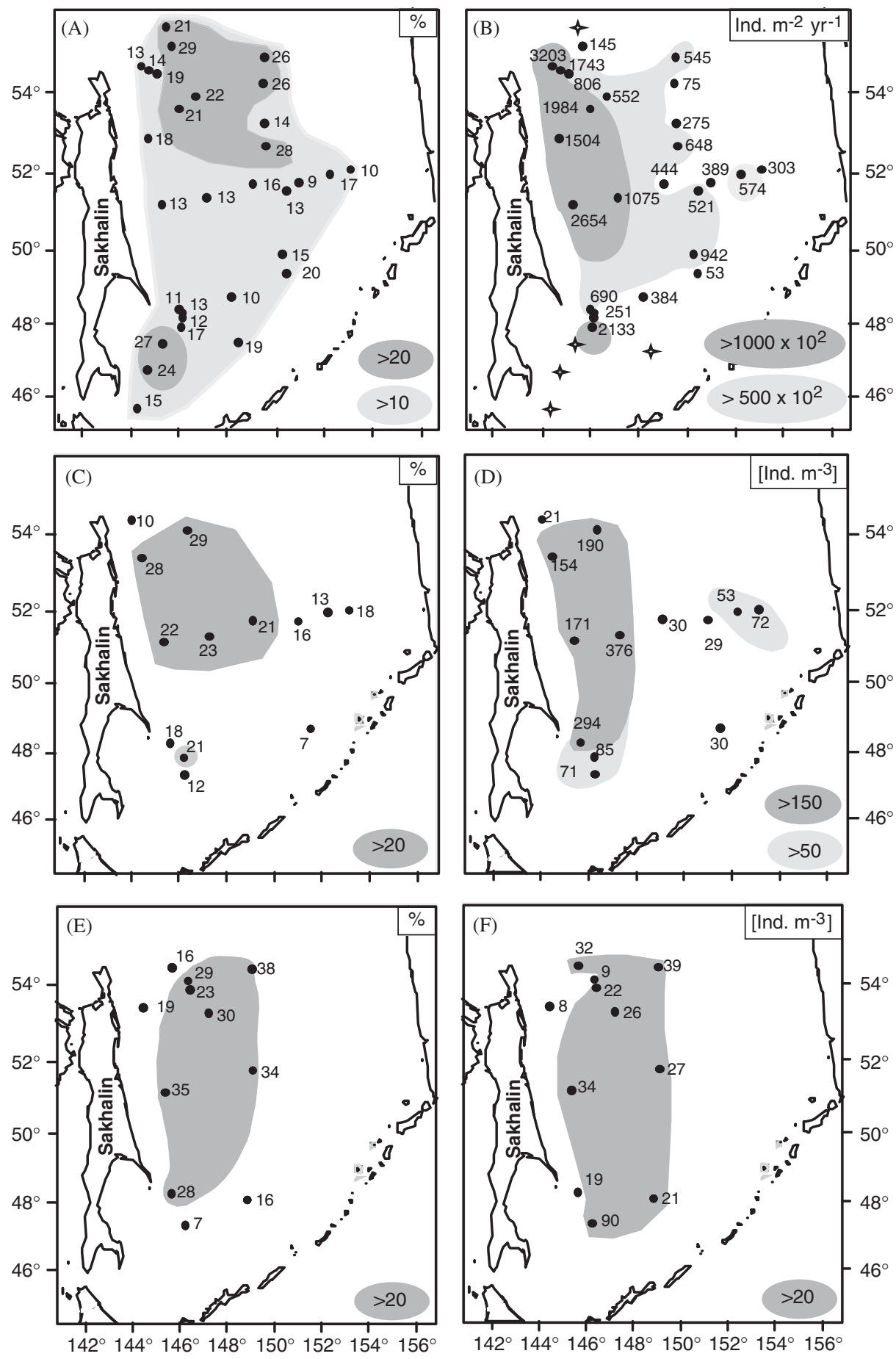

Fig. 13. Comparison of the distribution pattern of Cycladophora davisiana in surface sediments with its latitudinal distribution in the upper SOk Intermediate Water that occurs in 200-500 $\mathrm{m}$ water depth. Indicated are (A) relative abundances and (B) accumulation rates in surface sediments, (C) relative abundances, and (D) standing stocks during summer, (E) relative abundances, and (F) standing stocks during spring. Stations are marked with an asterisk where RAR could not be estimated due to lacking age assignment.

occurrence of a cold deep-water mass are combined and lead to an increased production of $C$. davisiana in these areas.
The glacial high $C$. davisiana abundances in northern and southern high-latitude oceans reflect the occurrence of a cold deep-water mass, strongly 
related to sea-ice formation. In the Southern Ocean, where relative and absolute abundance records of $C$. davisiana generally show a uniform pattern (Abelmann, unpubl. data), the species can be further applied to reconstruct a productivity regime related to high export of organic matter to mesopelagic depth that, according to Hays and Morley (2003), is indicative for high mesopelagic carbon consumption and regeneration. The establishment of such a system does not exclude a temporal sea-surface stratification. Persistence of such a stratification in an open glacial ocean such as the Southern Ocean is still under debate (Stephens and Keeling, 2000; Keeling et al., 2001; Morales Marqueda and Rahmsdorf, 2002), and high abundances of $C$. davisiana do not necessarily indicate the existence of a stable sea-surface stratification.

$D$. hirundo is the most dominant species in the lower SOIW, between 500 and $1000 \mathrm{~m}$ (Figs. 4 and 6.15-6.16; Tables 4 and 5). The other species that are somewhat important, but exhibit distinctly lower loadings in the factor analysis than $D$. hirundo, are Lophospyris sp. 1, Peridium sp. 1, Pseudodictyophimus gracilipes, Actinomma spp., and the Plagoniidae group (Table 2). We focus here on $D$. hirundo, as it represents a potential indicator to reconstruct past deep-water conditions. The species is considered to be cosmopolitan (Boltovskoy and Riedel, 1980). However, there is only little information available about its habitat. The pronounced distribution of the species in the lower SOIW of the SOk might be related to the specific productivity regime established during summer and fall that leads to a high export of phytodetritus to the deep ocean. Further, the specific hydrographic conditions in the SOk might influence the distribution of the species. Highest standing stocks of $D$. hirundo occur during summer close to the productive shelf area off Sakhalin, whereas during spring the standing stock values are relatively low (Fig. 14). The only increased numbers during this period are in the southwestern part of the SOk and might be related to the productivity maximum of phaeodarians in this area and enhanced phytodetritus export (Nimmergut and Abelmann, 2002). The summer productivity pattern of $D$. hirundo also is reflected in the surface-sediment record (Fig. 14). Highest accumulation rates of $D$. hirundo prevail in the central part of the SOk and in the southwestern part where water depth exceeds $1000 \mathrm{~m}$. The close relation of the species to the summer productivity regime of the SOk is in agreement with the results from a sediment trap located in the northeastern SOk, where the maximum flux starts in late summer and extends into the beginning of December (Hays and Morley, 2003). D. hirundo is only recorded in the deep trap at $1061 \mathrm{~m}$, which supports the depth habitat described from the plankton data. The relative abundances of the species in the lower SOIW during summer and spring show a rather uniform distribution over the central part of the SOk (Fig. 14). In surface sediments, maximum percentages of $D$. hirundo are concentrated in the northern and southern part of the sea and reflect its close relation to water depth (Fig. 14). The northern and southwestern parts of the SOk are characterized by enhanced vertical mixing that leads to the formation of SOIW (Kitani, 1973; Wong et al., 1998). Whereas in the northwestern part the influence of cold shelf water dominates the watermass properties, the southwestern part is strongly affected by a combination of several factors: the inflow of North Pacific water, warmer and saltier Japan Sea water, shelf water from the southwestern shelf of Sakhalin, and the Sakhalin Current that favors the formation of anti-cyclonic eddies and vertical mixing (Bulatov et al., 1999; Kitani, 1973). We conclude from these data that $D$. hirundo is related to an environment characterized by mixing processes that transport oxygen to the deep ocean and enhanced nutrient supply via export of organic matter released from highly productive surface waters to the deep ocean.

\subsection{Western Kurile Basin assemblage}

The radiolarian assemblage in surface sediments of the western part of the Kurile Basin is dominated by radiolarian species such as Lithomelissa setosa (Figs. 6.5-6.8 and 13; Table 3), Siphocampe arachnea (Figs. 6.11-6.12 and 15; Table 3), and Stylatractus (?) pyriformis (Figs. 7.19-7.20 and 15; Table 3), that are neither recorded from plankton nor sediment trap studies of the SOk (Nimmergut and Abelmann, 2002; Hays and Morley, 2003; Okazaki et al., 2003). For this reason no information about depth habitat and seasonal distribution pattern of these species in the SOk is available. $L$. setosa is a dominant species reported from the eastern subarctic Pacific, Bering Sea and the Norwegian Sea. Sediment trap studies from the eastern subarctic Pacific show that L. setosa displays a pronounced spring maximum (Takahashi, 1997). Increasing fluxes during spring also have been 

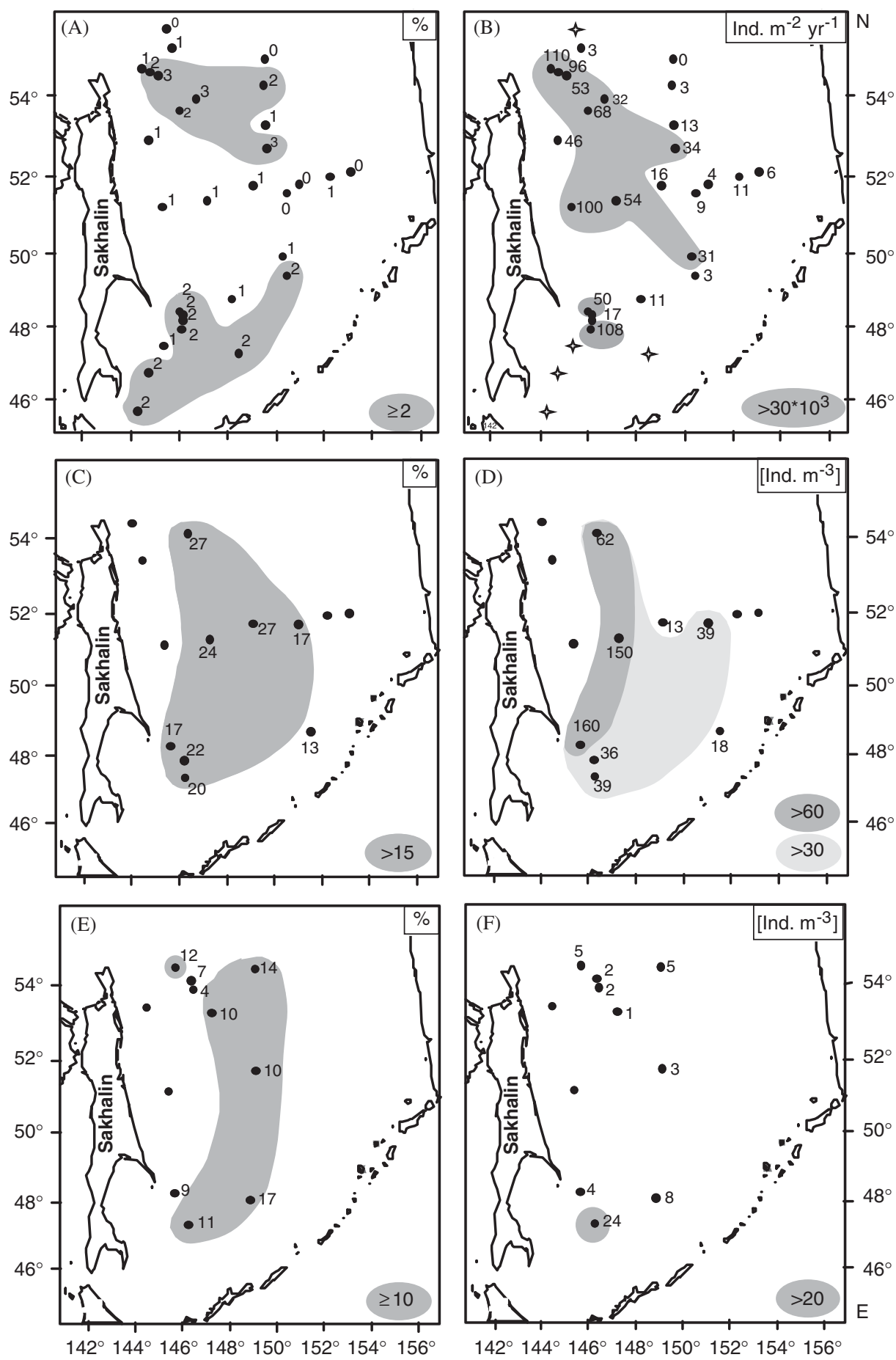

Fig. 14. Comparison of the distribution pattern of Dictyophimus hirundo in surface sediments with its latitudinal distribution in the lower SOk Intermediate Water that occurs in 500-1000 m water depth. Indicated are (A) relative abundances and (B) accumulation rates in surface sediments, (C) relative abundances, and (D) standing stocks during summer, (E) relative abundances, and (F) standing stocks during spring. Stations are marked with an asterisk where RAR could not be estimated due to lacking age assignment. 
reported from the Bering Sea (Itaki and Takahashi, 1995; Takahashi, 1997). L. setosa presents a common member of the radiolarian assemblage in the Atlantic domain and central gyre of the Norwegian Sea, where warm and cold waters are mixing (Bjørklund et al., 1998). However, it is absent or occurs only sporadically and in low numbers in the Iceland/Greenland Seas and in the Arctic Ocean (Bjørklund et al., 1998; Bjørklund and Kruglikova, 2003). Petrushevskaya (1968) described a closely related species, which she called Lithomelissa sp. A, from the Southern Ocean. This form is a common member of the surface-sediment assemblage south of the Polar Front (Abelmann, unpubl. data) and is also documented in deep sediment traps (below $500 \mathrm{~m}$ ) of a mooring from the Bransfield Strait (Abelmann, 1992a, b). The maximum of the species in this area was observed during austral spring (Abelmann, 1992a). The depth habitat of Lithomelissa sp. A is supported by plankton studies from the Southern Ocean, where the species was found at water depths between 400 and $1000 \mathrm{~m}$, located in the Antarctic Circum Polar Deep Water (Abelmann and Gowing, 1997). Matul (1998) reported high percentages of a taxon that he called L. setosa (but which is similar to Lithomelissa sp. A, Matul, personal com.), from surface sediments, located on the shallow shelf of the Benguela Upwelling area, where it might have been upwelled with deep source waters. As it is still not yet resolved if the specimens reported from the Southern and Northern Hemisphere are belonging to the same species, we only suggest that L. setosa in the SOk inhabits deeper water layers.

$S$. arachnea is widely distributed in the world ocean and has been found in water depths of about $1000 \mathrm{~m}$ (Kling and Boltovskoy, 1995). Similar to $L$. setosa, this species is one of the dominant species in deep sediment traps located in the subarctic Pacific and Bering Sea, where maximum fluxes occur during spring (Itaki and Takahashi, 1995). Maximum spring fluxes of $S$. arachnea also are reported from a deep sediment trap from the area of Meiji Guyot in the western subarctic Pacific (Tsoi et al., 1998), which supports the spring dominance of the species.

S. (?) pyriformis is reported from the Meiji Guyot sediment trap in low numbers throughout the year (Tsoi et al., 1998). In SOk surface sediments, it exhibits a distribution pattern similar to L. setosa and $S$. arachnea (Fig. 15).
We assume that the occurrence of L. setosa, S. arachnea, and $S$. (?) pyriformis in the southeastern Kurile Basin (Fig. 15) is strongly related to specific water-mass properties and food supply that might be steered by the inflow of warm Japan Sea water via the Soya Strait and North Pacific influence. The inflow of warm Japan Sea water into the SOk increases in spring (Takizawa, 1982) and favors the early warming and mixing of the water column as well as the development of early phytoplankton blooms. L. setosa and $S$. arachnea are small nassellarians feeding on phytodetritus and/or bacteria, whereas $S$. (?) pyriformis is a small spumellarian that may be herbivor, feeding directly on phytoplankton.

\section{Conclusion}

The comparison of the distribution pattern of radiolarians in surface sediments and water column (spring and summer) shows that maximum accumulation of radiolarians and standing stocks occur in the western SOk close to Sakhalin. The radiolarian standing stock data indicate that the signal preserved in the sediment record is mainly generated during summer and early fall season, which is in agreement with sediment trap studies of the SOk (Hays and Morley, 2003; Okazaki et al., 2003). The area off Sakhalin provides ideal environmental conditions for the mesopleagic radiolarian fauna, because of its steep shelf slope, high nutrient supply via the Amur River, and mixing processes at the shelf slope. The combination of high phytoplankton production and sea-surface stratification favors the enhanced mesopelagic biomass activity during summer.

The mesopelagic radiolarian fauna in the SOk is mainly composed of nassellarians that feed on phytodetritus and/or bacteria whereas the few spumellarians feed on phytoplankton or on small zooplankton. The mapping of specific radiolarian species in distinct water layers in comparison to their distribution in surface sediments provides detailed ecological information indicating that food supply, type of food, and water-mass properties primarily control the habitat of radiolarians. It seems that radiolarians follow specific strategies to select their habitat in order to secure their food resources in competition to other species.

The study shows that some taxa such as the Plagoniidae group and $C$. borealis that live in relatively broad depth ranges in the upper 500 and 

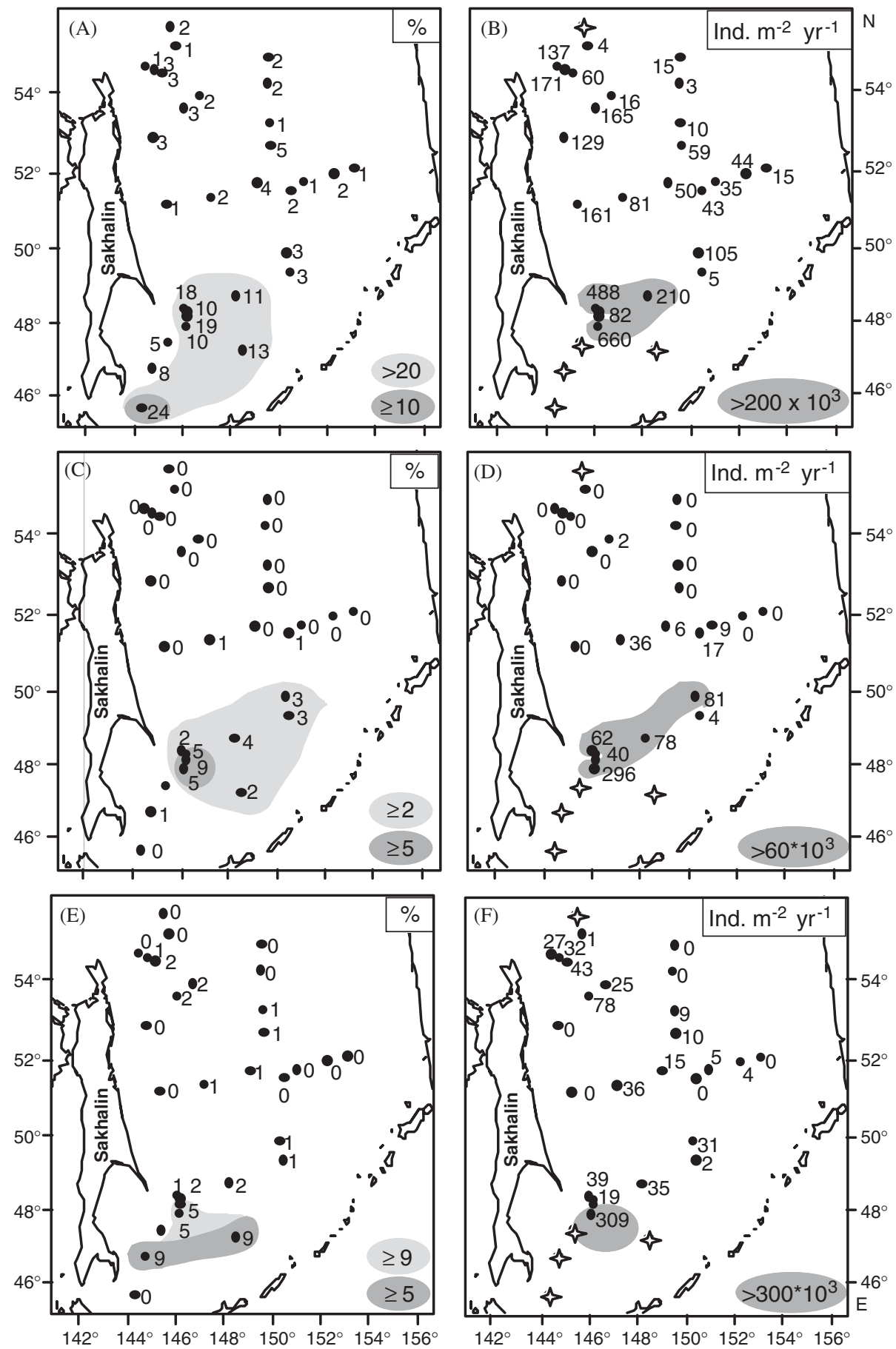

Fig. 15. The distribution pattern of Lithomelissa setosa, Siphocampe arachnea, and Stylatractus (?) pyriformis in surface sediments of the SOk. The species dominate the western Kurile assemblage. Indicated are (A) relative abundances and (B) accumulation rates of $L$. setosa, (C) relative abundances, and (D) accumulation rates of $S$. arachnea, (E) relative abundances, and (F) accumulation rates of $S$. (?) pyriformis. Stations are marked with an asterisk where RAR could not be estimated due to lacking age assignment.

$1000 \mathrm{~m}$ of the water column, have a more opportunistic behavior and are predominantly controlled by food supply. Opportunistic behavior also might govern the distribution of $R$. boreale. In contrast to the former species, $R$. boreale is restricted to subsurface depth $(150-200 \mathrm{~m})$ below the SODL 
temperature minimum, but it changes its latitudinal distribution and migrates in this specific water layer to different areas in the SOk.

A species strongly related to water-mass characteristics is Antarctissa (?) sp. 1, which inhabits the temperature minimum zone between 50 and $150 \mathrm{~m}$ and has its highest abundances in plankton and surface sediments of the western SOk during summer where the SODL is strongly established. The species is directly related to the development of the SODL.

Water-mass characteristics also control the habitat of $C$. davisiana and D. hirundo, both living in the SOIW. C. davisiana inhabits mainly the upper SOIW, which is strongly affected by the formation of cold shelf water produced during sea-ice formation. D. hirundo occurs in the lower SOIW, which exhibits slightly warmer temperatures than the upper SOIW. The relation to water masses is also reflected in the relative abundance pattern of both species, whose maximum distribution is in the area of intensive mixing and formation of SOIW. The second parameter that strongly affects the abundant occurrences of $C$. davisiana is the amount of organic matter exported from the surface to the deep ocean. This relation is exposed in the highly summer standing stock and high accumulation rates in surface sediments of $C$. davisiana in the high productivity area off Sakhalin. We thus conclude that high numbers of $C$. davisiana are controlled by two parameters: (1) the occurrence of a cold and well ventilated intermediate/deep water, and (2) enhanced export of organic matter from a highly productive surface to the deep ocean. Therefore, $C$. davisiana is an indicator for high export of organic matter into a cold mesopelagic layer.

One of the few radiolarians that can survive in the upper sea-surface layer, affected by strong seasonal changes, is the spumellarian S. venustum. However, the generally low numbers of $S$. venustum in plankton and surface sediments indicate that the surface layer of the SOk is not the ideal habitat for the species. This is also indicated in the distribution pattern of $S$. venustum in surface sediments where increased numbers occur in the more temperate area of the eastern part of the SOk that is strongly influence by the Kamchatka Current.

The western Kurile assemblage that is only documented in surface sediments of the western Kurile Basin is dominated by the nassellarians $L$. setosa and $S$. arachnea and the spumellarian $S$. (?) pyriformis. The occurrences of the species in this area seem to be controlled by an environment established under the influence of North Pacific waters and warm Japan Sea water advected via the Soya Strait.

\section{Acknowledgments}

We gratefully acknowledge the constructive criticism provided by Jane Dolven and one anonymous reviewer. We thank Alexander Matul for preparing the plates and G. Cortese for constructive remarks. For technical support we are indebted to Tanja Pollak. The crews of R.V. "Akademik M.A. Lavrentyev", "Utyos", and "Marshal Gelovani" are thanked for their excellent technical assistance on board. This research was supported by the German Federal Ministry for Education, Research and Technology (BMBF) in the frame of the RussianGerman research project KOMEX (Kurile Okhotsk Sea Marine Experiment).

\section{References}

Abelmann, A., 1988. Freeze-drying simplifies the preparation of microfossils. Micropaleontology 34, 361.

Abelmann, A., 1992a. Radiolarian flux in Antarctic waters (Drake Passage, Powell Basin, Bransfield Strait). Polar Biology 12, 357-372.

Abelmann, A., 1992b. Radiolarian taxa from Southern Ocean traps (Atlantic sector). Polar Biology 12, 373-385.

Abelmann, A., Gersonde, R., 1991. Biosiliceous particle flux in the Southern Ocean. Marine Chemistry 35, 503-536.

Abelmann, A., Gowing, M.M., 1997. Spatial distribution pattern of living polycystine radiolarian taxa-baseline study for paleoenvironmental reconstructions in the Southern Ocean (Atlantic sector). Marine Micropaleontology 30, 3-28.

Abelmann, A., Brathauer, U., Gersonde, R., Sieger, R., Zielinski, U., 1999. Radiolarian-based transfer function for the estimation of sea surface temperatures in the Southern Ocean (Atlantic sector). Paleoceanography 14 (3), 410-421.

Agatova, A.I., Dafner, E.V., Sapozhnikov, V.V., Torgunova, N.I., Ukolova, T.K., 1996. Investigations of dissolved and suspended organic matter distribution in the Sea of Okhotsk. Oceanology 36 (6), 808-815.

Alfultis, M.A., Martin, S., 1987. Satellite passive microwave studies of the Sea of Okhotsk ice cover and its relation to Oceanic Processes, 1978-1982. Journal of Geophysical Research 92 (C12), 13013-13028.

Anderson, O.R., 1983. Radiolaria. Springer, New York, Berlin, Heidelberg, Tokyo, pp. 1-355.

Anderson, O.R., Bennett, P., Dror, A., Bryan, M., 1989. Experimental and observational studies of radiolarian physiological ecology: 2. Trophic activity and symbiont primary productivity of Spongaster tetras tetras with comparative data a predatory activity of some Nassellarida. Marine Micropaleontology 14 (4), 267-273. 
Arzhanova, N.V., Naletova, I.A., 1999. Hydrochemical structure, mesoscale eddies, and primary production in the Northern Part of the Sea of Okhotsk. Oceanology 39 (5), 675-682.

Azam, F., Fenchel, T., Field, J.G., Gray, J.S., Meyer-Reil, L.A., Thingstad, F., 1983. The ecological role of water column microbes in the sea. Marine Ecology Progress Series 10, 257-263.

Barnett, P.R.O., Watson, J., Connelly, D., 1984. A multiple corer for taking virtually undisturbed samples from shelf, bathyal and abyssal sediments. Oceanologica Acta 7, 399-408.

Biebow, N., Hütten, E. (Eds.), 1999. Cruise Reports: KOMEX I and II. R.V. Professor Gagarinsky Cruise 22, R.V. Akademik M.A. Lavrentyev Cruise 28, GEOMAR Report 82 (188pp).

Biebow, N., Luedmann, T., Karp, B.Ya., Kulinich, R., 2000. Cruise Reports KOMEX V and VI. R.V. Professor Gagarinsky Cruise 26, M.V. Marshal Gelovany Cruise 1, GEOMAR Report 88 (296pp).

Biebow, N., Kulinich, R., Baranov, B., et al., 2003. Cruise Reports. R.V. Akademik M.A. Lavrentyev Cruise 29, Leg 1 and Leg 2, GEOMAR Report 110.

Bjørklund, K.R., Kruglikova, S.B., 2003. Polycystine radiolarians in surface sediments in the Arctic Ocean basins and marginal seas. Marine Micropaleontology 49, 231-273.

Bjørklund, K.R., Cortese, G., Swanberg, N., Schrader, H.J., 1998. Radiolarian faunal provinces in surface sediments of the Greenland, Iceland and Norwegian (GIN) Seas. Marine Micropaleontology 35 (1-2), 105-140.

Boltovskoy, D., Riedel, W.R., 1980. Polycystine radiolaria from the southwestern Atlantic Ocean plankton. Revista Española de Micropaleontologia 12 (1), 99-146.

Broerse, A.T.C., Ziveri, P., Honjo, S., 2000. Coccolithophore $\left(-\mathrm{CaCO}_{3}\right)$ flux in the Sea of Okhotsk: seasonality, settling and alteration processes. Marine Micropaleontology 39, 179-200.

Bulatov, N.V., Kurennaya, L.A., Muktepavel, S., Aleksanina, M.G., Gerbek, E.E., 1999. Eddy water structure in the southern Sea of Okhotsk and its seasonal variability (results of satellite monitoring). Oceanology 39, 29-37.

Dolven, J.K., Bjørklund, K.R., 2001. An early Holocene peak occurrence and recent distribution of Rhizoplegma boreale (Radiolaria): a biomarker in the Norwegian Sea. Marine Micropaleontology 42, 25-44.

Freeland, H.J., Bychkov, A.S., Whitney, F., Tayler, C., Wong, C.S., Yurasov, G.I., 1998. WOCE section P1W in the Sea of Okhotsk 1. Oceanographic data description. Journal of Geophysical Research 103 (C8), 15613-15623.

Hays, J.D., Morley, J.J., 2003. The Sea of Okhotsk: a window on the ice age ocean. Deep-Sea Research I 50, 1481-1506.

Itaki, T., 2003. Depth-related radiolarian assemblage in the water-column and surface sediments of the Japan Sea. Marine Micropaleontology 47, 253-270.

Itaki, T., Takahashi, K., 1995. Preliminary results on radiolarian fluxes in the central subarctic Pacific and Bering Sea. Proceedings of the Hokkaido Tokai University Science and Engineering 7, 37-47 (in Japanese with English Abstract).

Itaki, T., Ito, M., Narita, M., Ahagon, N., Sakai, H., 2003. Depth distribution of radiolarians from the Chukchi and Beaufort Seas, western Arctic. Deep-Sea Research I 50, 1507-1522.

Jacot des Combes, H., Abelmann, A., submitted. Radiolarianbased reconstruction of upwelling activity off Lüderitz (SE Atlantic) for the last $250 \mathrm{ka}$ : implications for paleoceanographic changes in the Benguela upwelling system. Marine Micropaleontology, submitted for publication.
Jørgensen, E., 1905. The protist plankton and the diatoms in bottom samples. Bergens Museums Skrifter 7, 49-225.

Kaiser, A., 2001. Ozeanographie, Produktivität und Meereisverbreitung im Ochotskischen Meer während der letzten ca. 350.000 Jahre. Ph.D. Thesis, Christian Albrechts University, Kiel, p. 113.

Keeling, R.F., Visbeck, M., Sigman, D., Boyle, E.A., 2001. Antarctic stratification and glacial $\mathrm{CO}_{2}$. Nature 412, 605-607.

Kitani, K., 1973. An oceanographic study of the Okhotsk Seaparticularly in regard to cold waters. Bulletin Far Seas Fisheries Research Laboratory 9, 45-75.

Kling, S.A., Boltovskoy, D., 1995. Radiolarian vertical distribution across the southern California Current. Deep-Sea Research I 42 (2), 191-231.

Kruglikova, S.B., 1975. Radiolarians in the surface layer of sediments in the Sea of Okhotsk. Oceanology 15 (1), 82-86.

Kuhn, G., Dunker, E., 1994. Der Minicorer, ein Gerät zur Beprobung der Sediment/Bodenwasser-Grenze, Greifswalder Geowissenschaftl. Beiträge Reihe A 2, 99-100.

Lapshina, V.J., 1996. Quantitative seasonal and year-to year changes of phytoplankton in the Okhotsk Sea and off Kuril Area of the Pacific. In: Nagata, Y., Lobanov, V.B., Talley, L.D. (Eds.) Proceedings of the Workshop on the Okhotsk Sea and Adjacent Area. PICES Scientific Report 6, pp. 240-246.

Ling, H.-Y., 1974. Polycystine Radiolaria and silicoflagellates from surface sediments of the Sea of Okhotsk. Bulletin of Geological Survey of Taiwan 24, 1-11.

Ling, H.-Y., Stadium, C.J., Welch, M.L., 1971. Polycystine radiolaria from Bering Sea surface sediments. In: Farinacci, A. (Ed.), Proceedings of the Second Planktonic Conference, Roma 1970. Tecnoscienza, pp. 705-729.

Lisitzin, A.P., 1996. Oceanic sedimentation: lithology and geochemistry. In: Kennett, J.P. (Ed.), English Translation. American Geophysical Union, Washington, DC, p. 400.

Matul, A.G., 1998. On the Radiolaria from the surface layer of the bottom sediments of the northern sector of the Benguela upwelling. Oceanology 38 (5), 687-692.

Morales Marqueda, M.A., Rahmsdorf, S., 2002. Did Antarctic sea-ice expansion cause glacial $\mathrm{CO}_{2}$ decline? Geophysical Research Letters 29, 111-113.

Mordasova, N.V., 1997. Some peculiarities of chlorophyll distribution in the Sea of Okhotsk. Oceanology 37 (4), 484-491.

Morley, J.J., Hays, J.D., 1983. Oceanographic conditions associated with high abundances of the radiolarian Cycladophora davisiana. Earth and Planetary Science Letters 66, 63-72.

Morley, J.J., Stepien, J.C., 1985. Antarctic Radiolaria in late winter/early spring Weddell Sea waters. Micropaleontology 31 (4), 365-371.

Nimmergut, A., Abelmann, A., 2002. Spatial and seasonal changes of radiolarian standing stocks in the Sea of Okhotsk. Deep-Sea Research I 49, 463-493.

Nishimura, A., Nakaseko, K., Okuda, Y., 1997. A new coastal water radiolarian assemblage recovered from sediment samples from the Antarctic Ocean. Marine Micropaleontology $30,29-44$.

Nürnberg, D., Baranov, B.V., Karp, B.Ya., 1997. R.V. Akademik M.A. Lavrentyev Cruise 27-cruise report: GREGORY. GEOMAR Report 60 (69pp).

Nürnberg, D., Tiedemann, R., Kaiser, A., Biebow, N., Pedersen, U., 2001. The Sea of Okhotsk-NW-Pacific high resolution 
paleoceanographic and paleoclimatic archive. In: Seventh International Conference on Paleoceanography, September 16-22, 2001, Sapporo, Japan. Program and Abstracts, p. 164.

Okazaki, Y., Takahashi, K., Yoshitani, H., Nakatsuka, T., Ikehara, M., Wakatsuchi, M., 2003. Radiolarians under seaice covered conditions in the Sea of Okhotsk: flux and their implications for paleoceanography. Marine Micropaleontology 49, 195-230.

Petrushevskaya, M., 1968. Radiolarian of orders Spumellaria and Nassellaria of the Antarctic region. In: Andriyashev, A.P., Ushakov, P.V. (Eds.), Biological Report of the Soviet Antarctic Expedition (1955-1958), vol. 3. Academy of Sciences of the USSR, Israel Program for Scientific Translations, Jerusalem, pp. 2-186.

Rogachev, K.A., 2000. Recent variability in the Pacific western subarctic boundary currents and Sea of Okhotsk. Progress in Oceanography 47, 299-336.

Samtleben, C., et al., 1995. Plankton in the Norwegian-Greenland Sea: from living communities to sediment assemblagesan actualistic approach. Geologische Rundschau 84 (1), $108-136$.

Sapozhnikov, V.V., Gruzevich, A.K., Arzhanova, N.V., Naletova, I.A., Zubarevich, V.L., Sapozhnikov, M.V., 1999. Principal features of spatial distribution of organic and inorganic nutrient compounds in the Sea of Okhotsk. Oceanology 39 (2), 198-204.

Schröder-Ritzrau, A., 1995. Aktuopaläontologische Untersuchung $\mathrm{zu}$ Verbreitung und Vertikalfluss von Radiolarien sowie ihre räumliche und zeitliche Entwicklung im Europäischen Nordmeer. Ph.D. Thesis, Berichte Sonderforschungsbereich 313, Univ. Kiel 52, pp. 1-99.

Sieger, R., Gersonde, R., Zielinski, U., 1999. A new extended software package for quantitative paleoenvironmental reconstructions. Eos 80 (19), 223.

Sorokin, Y.I., 1978. Decomposition of organic matter and nutrient regeneration. In: Kinne, O. (Ed.), Marine Ecology. Wiley, London, pp. 501-616.

Sorokin, Y.I., Sorokin, P.Yu., 1999. Production in the Sea of Okhotsk. Journal of Plankton Research 21 (2), 201-230.

Stephens, B., Keeling, R., 2000. The influence of Antarctic sea ice on glacial-interglacial $\mathrm{CO}_{2}$ variations. Nature 404, 171-174.
Takahashi, K., 1997. Time-series fluxes of radiolaria in the eastern subarctic Pacific Ocean. News of Osaka Micropaleontologists, Special Volume 10, 299-309.

Takahashi, K., Fujitani, N., Yanada, M., 2002. Long-term monitoring of particle fluxes in the Bering Sea and the central subarctic Pacific Ocean, 1990-2000. Progress in Oceanography 55, 95-112.

Takizawa, T., 1982. Characteristics of the Soya warm current in the Okhotsk Sea. Journal of the Oceanographical Society of Japan 38, 281-292.

Talley, D., Nagata, Y. (Eds.), 1995. The Sea of Okhotsk and Oyashia Region. PICES Scientific Report 2. North Pacific Marine Science Organisation (PICES), Sidney, Canada pp. $1-227$.

Tsoi, I.B., Shastina, V.V., Biryulina, M.G., 1998. Seasonal fluxes of microplankton in the Meiji Guyot Area (Northwestern Pacific). Russian Journal of Marine Biology 24 (5), 306-312.

Wailes, G.H., 1937. Canadian Pacific Fauna. 1. Protozoa (9-14). The University of Toronto Press.

Welling, L.A., Pisias, N.G., Roelofs, K., 1992. Radiolarian microfauna in the northern California Current system; indicator of multiple process controlling productivity. In: Summerhayes, C.P., Prell, W.L., Emeis, K.C. (Eds.), Upwelling Systems: Evolution since the early Miocene, vol. 64. Geological Society Special Publication, pp. 177-195.

Winkler, G., 2000. Tracer oceanographic aspects of the Sea of Okhotsk: new results from tritum, helium and oxygen isotope data. In: Third Workshop on Russian-German Cooperation in the Sea of Okhotsk-Kurile Island Arc System, Program and Abstracts, Moscow.

Winkler, G., Sosnin, V., Salyuk, A., 1999. Hydrography of the Sea of Okhotsk. In: Biebow, N., Hütten, E.E. (Eds.), Cruise reports: KOMEX I and II. Geomar Report 82, Kiel.

Wong, C.S., Matear, R.J., Freeland, H.J., Whitney, F.A., Bychkow, A.S., 1998. WOCE line P1W in the Sea of Okhotsk 2. CFCs and the formations rate of intermediate water. Journal of Geophysical Research 103 (C8), 15625-15642.

Yang, J., Honjo, S., 1996. Modeling the near-freezing dicothermal layer in the Sea of Okhotsk and its interannual variations. Journal of Geophysical Research 101 (C7), 16421-16433.

Yasuoka, T., 1967. Hydrography in the Okhotsk Sea (1). The Oceanographical Magazine 19, 61-72. 